\title{
Key Impact of an Uncommon Plasmid on Bacillus amyloliquefaciens subsp. plantarum S499 Developmental Traits and Lipopeptide Production
}

\author{
Giulia Molinatto ${ }^{1}$, Laurent Franzil ${ }^{2}$, Sébastien Steels ${ }^{2}$, Gerardo Puopolo ${ }^{1 * t}$, Ilaria Pertot ${ }^{1 \dagger}$ \\ and Marc Ongena ${ }^{2 \dagger}$ \\ ${ }^{1}$ Plant Pathology and Applied Microbiology Unit, Department of Sustainable Agro-Ecosystems and Bioresources, Research \\ and Innovation Centre, Fondazione Edmund Mach, San Michele all'Adige, Italy, ${ }^{2}$ Microbial Processes and Interactions \\ Research Unit, Gembloux Agro-Bio Tech Faculty, University of Liège, Gembloux, Belgium
}

OPEN ACCESS

Edited by:

Essaid Ait Barka,

University of Reims

Champagne-Ardenne, France

Reviewed by:

Zhenzhen Qiao,

University of Oklahoma, USA

Samir Jaoua

Qatar University, Qatar

*Correspondence:

Gerardo Puopolo

gerardo.puopolo@fmach.it

${ }^{\dagger}$ These authors have contributed equally to this work.

Specialty section:

This article was submitted to

Plant Biotic Interactions,

a section of the journal

Frontiers in Microbiology

Received: 27 October 2016 Accepted: 04 January 2017

Published: 19 January 2017

Citation:

Molinatto G, Franzil L, Steels S, Puopolo G, Pertot I and Ongena M (2017) Key Impact of an Uncommon Plasmid on Bacillus amyloliquefaciens subsp. plantarum 5499

Developmental Traits and Lipopeptide Production. Front. Microbiol. 8:17. doi: 10.3389/fmicb.2017.00017
The rhizobacterium Bacillus amyloliquefaciens subsp. plantarum S499 (S499) is particularly efficient in terms of the production of cyclic lipopeptides, which are responsible for the high level of plant disease protection provided by this strain. Sequencing of the S499 genome has highlighted genetic differences and similarities with the closely related rhizobacterium B. amyloliquefaciens subsp. plantarum FZB42 (FZB42). More specifically, a rare 8008 bp plasmid (pS499) harboring a rap-phr cassette constitutes a major distinctive element between S499 and FZB42. By curing this plasmid, we demonstrated that its presence is crucial for preserving the typical physiology of S499 cells. Indeed, the growth rate and extracellular proteolytic activity were significantly affected in the cured strain (S499 $\mathrm{P}^{-}$). Furthermore, pS499 made a significant contribution to the regulation of cyclic lipopeptide production. Surfactins and fengycins were produced in higher quantities by S499 $\mathrm{P}^{-}$, whereas lower amounts of iturins were detected. In line with the increase in surfactin release, bacterial motility improved after curing, whereas the ability to form biofilm was reduced in vitro. The antagonistic effect against phytopathogenic fungi was also limited for S499 $\mathrm{P}^{-}$, most probably due to the reduction of iturin production. With the exception of this last aspect, S499 $\mathrm{P}^{-}$behavior fell between that of S499 and FZB42, suggesting a role for the plasmid in shaping some of the phenotypic differences observed in the two strains.

Keywords: Bacillus, genome comparison, plasmid, surfactin, biological control

\section{INTRODUCTION}

Some strains of the Bacillus amyloliquefaciens species have been described as beneficial rhizobacteria, because of their ability to promote growth and/or protect plants from infection by multiple pathogens (Lugtenberg and Kamilova, 2009; Cawoy et al., 2011; Kumar et al., 2011). This protective effect against disease is achieved through multiple mechanisms, of which competition for space/nutrients, direct antibiosis against pathogens, and induction of systemic resistance (ISR) in the host plant are the most relevant (Nihorimbere et al., 2011; Bakker et al., 2013). Borriss et al. (2011) separated this bacterial species into two taxa "B. amyloliquefaciens subspecies amyloliquefaciens" and "B. amyloliquefaciens subspecies plantarum," which grouped together all the plant-associated B. amyloliquefaciens strains. Recently, the 
B. amyloliquefaciens subspecies plantarum has undergone two reclassifications as a later heterotypic synonym of $B$. methylotrophicus (Dunlap et al., 2015), and then as B. velezensis (Dunlap et al., 2016). The commercially available strain B. amyloliquefaciens FZB42 (FZB42; RhizoVital ${ }^{\circledR}$ 42, Abitep $\mathrm{GmbH}$ ) is considered as the type strain of this "plantarum" subspecies. This is based on its genetic richness in key genes or clusters involved in its plant-associated lifestyle and the synthesis of bioactive secondary metabolites (BSM) acting as signals for intra- or inter-species cross-talks (e.g., stimulation of ISR), and/or as antimicrobials for suppressing competitors in the rhizosphere (Koumoutsi et al., 2004; Chen et al., 2007, 2009; Borriss et al., 2011; Chowdhury et al., 2015).

As part of this BSM arsenal, surfactins, fengycins, and iturins are the three main families of cyclic lipopeptides (CLPs) produced by the Bacillus amyloliquefaciens species, synthesized in an mRNA-independent way by modular enzymes (nonribosomal peptide synthetases, NRPS, or hybrid polyketide synthases/non-ribosomal peptide synthetases, PKS-NRPS; Walsh, 2004). These compounds have multiple functions that are crucial both for rhizosphere fitness of the producing strains but also for their biocontrol potential (Ongena et al., 2005a; Ramarathnam et al., 2007; Romero et al., 2007; Ongena and Jacques, 2008; Kim et al., 2010; Raaijmakers et al., 2010; Cawoy et al., 2015). Surfactins are heptapeptides linked to a $\beta$-hydroxy fatty acid (various homologs from C12 to C17) which display some ISR-eliciting activity and some antibacterial and antiviral activity, but are not fungitoxic (Peypoux et al., 1999; Ongena et al., 2007). As wetting agents, surfactins also help the movement of producing cells along the roots by facilitating swarming motility (Kinsinger et al., 2003; Julkowska et al., 2005; Leclère et al., 2006). Moreover, an essential role in the formation of biofilm on roots has been recognized for this CLP (Bais et al., 2004). Fengycins are lipodecapeptides with an internal lactone ring in the peptide moiety, plus a saturated or unsaturated $\beta$-hydroxy fatty acid chain (C14-C19), and show strong antifungal activity (Vanittanakom et al., 1986). Iturins include seven variants, of which bacillomycins and mycosubtilin are the best known; all of them are heptapeptides linked to a $\beta$-amino fatty acid chain (C14-C17). Iturins have limited antibacterial activity, but a strong antifungal effect (Maget-Dana and Peypoux, 1994). Fengycins and iturins have been shown to be essential for the ISR-independent biocontrol provided by several Bacillus strains (Ongena and Jacques, 2008; Raaijmakers et al., 2010).

Bacillus amyloliquefaciens subsp. plantarum S499 (S499) represents another strain that has been widely investigated due to its biocontrol potential, and more broadly in the context of molecular interaction with the host plant and other soil-borne microorganisms. S499 also synthesizes the three CLP families, but in quite different proportions compared to FZB42 and other Bacillus amyloliquefaciens subsp. plantarum strains, suggesting a divergent regulatory pathway in the synthesis of secondary metabolites (Cawoy et al., 2015). For instance, S499 is a very efficient producer of surfactins in vitro and in planta, which correlates with a higher potential for ISR induction compared to FZB42 and other strains belonging to the same subspecies
(Jacques et al., 1999; Cawoy et al., 2014). S499 is also quite distinct in terms of other phenotypic traits such as biofilm formation, motility and root colonization (Cawoy et al., 2014). In addition, some environmental factors and plant determinants influence CLP production in S499, making this strain a good model for studying multitrophic interaction in the rhizosphere ecosystem (Nihorimbere et al., 2012; Pertot et al., 2013; Debois et al., 2015). The genome of S499 has recently been sequenced, assembled, and annotated with the scope of pointing out some genetic determinants possibly related to its relatively specific behavior (CP014700-CP014701, Molinatto et al., 2016).

In the work presented here, we performed further comparative genomics, revealing some peculiarities in terms of genetic equipment and organization at chromosome level compared to the type strain FZB42. However, an additional feature of S499 is the presence of a plasmid (pS499) containing a rap-phr cassette encoding the response regulator aspartate phosphatase (Rap) and its putative Rap regulatory peptide (Phr). As RapPhr systems have pleiotropic regulatory effects on a number of cellular processes (Pottathil and Lazazzera, 2003), we pursued the functional characterisation of pS499 by evaluating how its loss affects S499 behavior compared to the type strain FZB42. Our data provide some evidence regarding the crucial impact of this plasmid on several traits related to rhizosphere competence, such as substrate utilization, cell motility, biofilm formation, and antagonism against fungal phytopathogens.

\section{MATERIALS AND METHODS}

\section{Bacterial and Fungal Strains}

All the bacterial strains used in this work (Table S1) were stored at length in glycerol $30 \%$ at $-80^{\circ} \mathrm{C}$ and routinely grown at $28^{\circ} \mathrm{C}$ in Luria-Bertani broth (LB; tryptone $10 \mathrm{gl}^{-1}$, yeast extract $5 \mathrm{gl}^{-1}$, $\mathrm{NaCl} 10 \mathrm{gl}^{-1}, \mathrm{pH} 7$ ) and on LB broth amended with agar $16 \mathrm{gl}^{-1}$ (LBA). The phytopathogenic fungi used in this work (Table S1) were grown on potato dextrose agar (PDA) at $28^{\circ} \mathrm{C}$ and stored at length on PDA slants at room temperature.

\section{Genome Comparative Analysis}

Phylogenetic analysis was carried out with Gegenees software 2.2.1 (Ågren et al., 2012) through fragmented all-against-all comparison (fragment size $=500$; sliding step size $=500$ ) performed on the sequences of $B$. amyloliquefaciens subsp. plantarum and closely related strains whose complete genome was present on NCBI (http://www.ncbi.nlm.nih.gov) on 14 March 2016. In particular, 19 strains belonging to different Bacillus species were included in the analysis. The heat plot tab generated by Gegenees was used to build the Neighbor-Joining phylogenetic tree with the Neighbor and DrawGram applications of the Phylogeny Inference Package (PHYLIP) version 3.695 (Felsenstein, 1989).

Genome alignment of the S499 genome against FZB42 was done with the sequence-based comparison tool on SEED Viewer version 2.0 (Overbeek et al., 2005). On the same platform, the BLAST tool was used to perform gene by gene sequence alignments. The genomes of FZB42 and S499 were also aligned by applying the progressive algorithm 
and maintaining the default settings implemented in opensource MAUVE aligner v2.3.1 (Darling et al., 2010). BRIG application (Alikhan et al., 2011) was used to display circular comparisons.

To assess the frequency of plasmids similar to the $\$ 499$ plasmid (pS499), the NCBI Genome Assembly, and Annotation reports for $B$. amyloliquefaciens subsp. plantarum and $B$. amyloliquefaciens subsp. amyloliquefaciens, and the NCBI Plasmid Annotation report for B. subtilis were examined (included sequences are listed in Table S2). Moreover, strains 23, 76, 98R, 98S, 104, and GA1 belonging to different Bacillus spp. were tested using PCR with Rap1 primers (Table S3) after isolation of plasmid DNA using a GeneJET Plasmid Miniprep kit (Thermo Fisher Scientific Inc.). The PCR program was as follows: $5 \mathrm{~min}$ at $95^{\circ} \mathrm{C}$, followed by 30 cycles of $30 \mathrm{~s}$ at $95^{\circ} \mathrm{C}, 30 \mathrm{~s}$ at $60^{\circ} \mathrm{C}$ and $1 \mathrm{~min}$ at $68^{\circ} \mathrm{C}$. Annotation of the pS499 sequence (CP014701) was done using Prokka (Seemann, 2014). The sequence encoding the Phr peptide was retrieved by aligning the $p h r Q$ gene (BAPNAU_RS20550, Wu et al., 2013) against the pS499 sequence. Alignments of the plasmid-encoded rap genes were performed on NCBI blastn suite (http://blast.ncbi.nlm.nih.gov/Blast.cgi) and with EMBOSS Needle Pairwise Sequence Alignment tools (http://www.ebi.ac. uk/Tools/psa/).

\section{Plasmid Curing}

Bacillus amyloliquefaciens subsp. plantarum S499 was cured of its native plasmid according to the procedure described by Feng et al. (2013), with some modifications. Briefly, S499 was grown for $16 \mathrm{~h}$ at $30^{\circ} \mathrm{C}(180 \mathrm{rpm})$ in sterile $15 \mathrm{ml}$ tubes containing $5 \mathrm{ml}$ of LB broth. The resulting cell culture was diluted 10 times in LB broth and $50 \mu \mathrm{l}$ were transferred to sterile 15 $\mathrm{ml}$ tubes containing $5 \mathrm{ml}$ of LB broth amended with $0.005 \%$ sodium dodecyl sulfate. Inoculated tubes were incubated at $42^{\circ} \mathrm{C}$ $(180 \mathrm{rpm})$ for $12 \mathrm{~h}$. This step was repeated 14 times. After each $12 \mathrm{~h}$ incubation, serial dilutions of the cell cultures were streaked on LBA dishes and incubated at $30^{\circ} \mathrm{C}$ for $24 \mathrm{~h}$. Selected colonies were picked up and total DNA was extracted using a PureLink Genomic DNA Mini Kit (Thermo Fisher Scientific Inc.) according to the manufacturer's instructions. The extracted total DNA was amplified in PCR reactions, where Rep primers (Table S3) specific for the pS499 sequence encoding rep gene were used. To rule out the possibility that potential plasmid cured derivatives were the result of contaminations, $16 \mathrm{~S}$ rDNA, cheA, gyrA genes from $\mathrm{S} 499$ and its derivatives were amplified using primer pairs reported in Table S3. In all the cases, the PCR programs consisted of a first step at $95^{\circ} \mathrm{C}$ for $5 \mathrm{~min}$ and 30 cycles in series of $30 \mathrm{~s}$ at $95^{\circ} \mathrm{C}, 30 \mathrm{~s}$ at $60^{\circ} \mathrm{C}, 1 \mathrm{~min}$ at $72^{\circ} \mathrm{C}$ and finally $5 \mathrm{~min}$ at $72^{\circ} \mathrm{C}$. The presence/absence of the rep amplicons was checked on a $1 \%$ agarose gel to select plasmid cured derivatives. Amplicons from 16S rDNA, cheA, gyrA genes were purified with illustra ExoProStar 1-Step (GE Healthcare Europe GmbH), and sequenced with an ABI PRISM 3730xl DNA analyzer (Applied Biosystems, Thermo Fisher Scientific Inc., USA). To determine the level of nucleotide sequence identity, sequences of $16 \mathrm{~S}$ rDNA, cheA, gyrA amplicons deriving from $\mathrm{S} 499$ and its derivative were subsequently aligned with EMBOSS Needle Pairwise Sequence Alignment tools (http://www.ebi.ac.uk/Tools/psa/).

\section{Growth Curves}

A SpectraMax M2E Multi-Mode Microplate Reader (Molecular Devices LLC, USA) was used to determine the growth rates of S499, and the plasmid-cured S499 strain (S499 $\left.\mathrm{P}^{-}\right)$. FZB42 was included in all the following assays as a comparison. The test was carried out in sterile 48 -well plates. A volume of 10 $\mu \mathrm{l}$ of a cell suspension [optical density at $600 \mathrm{~nm}\left(\mathrm{OD}_{600}\right)=$ 0.001 corresponding to the $10^{3}$ colony forming units (CFU)] was inoculated into LB broth $(1 \mathrm{ml})$ and a modified LB broth $(1 \mathrm{ml})$, where tryptone $\left(10 \mathrm{~g} \mathrm{l}^{-1}\right)$ was replaced by casamino acids $(10 \mathrm{~g}$ $1^{-1}$ ). Non-inoculated LB and modified LB broths were used as a control. The plate was incubated with continuous shaking for 40 $\mathrm{h}$ at $28^{\circ} \mathrm{C}$ and $\mathrm{OD}_{600}$ was measured every $30 \mathrm{~min}$. Three wells were used for each strain (replicates) and the experiment was repeated.

The supernatants of the 48-well LB cultures were filtered through a $0.2 \mu \mathrm{m}$ membrane (Sartorius AG, Germany) at the end of the incubation period ( $40 \mathrm{~h}$ ). To identify and quantify CLPs (surfactins, fengycins, and iturins), the culture filtrates of each strain were analyzed with ultra-performance liquid chromatography-electrospray ionization mass spectrometry (UPLC-ESI-MS) according to the procedure described below. Three repetitions of the assay were used to calculate the mean values of production.

\section{Extracellular Proteolytic Activity}

The FZB42, S499 and S499 $\mathrm{P}^{-}$strains were inoculated into $15 \mathrm{ml}$ sterile tubes containing $5 \mathrm{ml}$ of $\mathrm{LB}$ broth and grown overnight $(16 \mathrm{~h})$ at $28^{\circ} \mathrm{C}(180 \mathrm{rpm})$. The resulting cell cultures were diluted 100 times by transferring $50 \mu \mathrm{l}$ into sterile $15 \mathrm{ml}$ tubes containing $5 \mathrm{ml}$ of LB broth (three replicates for each strain). Once inoculated, $15 \mathrm{ml}$ tubes were incubated for $6 \mathrm{~h}$ in the same conditions reported above. $\mathrm{OD}_{600}$ was recorded at the end of the incubation period. Subsequently, tubes were centrifuged at $4000 \mathrm{rpm}$ for $10 \mathrm{~min}$ to remove the cells and the supernatants were filtered through a $0.2 \mu \mathrm{m}$ membrane (Sartorius AG). A volume of $225 \mu \mathrm{l}$ of culture filtrates (three replicates for each tube) was transferred to $1.5 \mathrm{ml}$ sterile microfuge tubes and mixed with $150 \mu$ l of $1 \%$ azocasein stock solution $(50 \mathrm{mM}$ Tris- $\mathrm{HCl}, \mathrm{pH}$ 8.8). After $4 \mathrm{~h}$ of incubation at $37^{\circ} \mathrm{C}$, the undigested substrate was precipitated by adding $375 \mu \mathrm{l}$ of $5 \%$ trichloroacetic acid and centrifuged for $3 \mathrm{~min}$ at 13,200 rpm. Supernatants were transferred to new $1.5 \mathrm{ml}$ sterile microfuge tubes containing 400 $\mu l$ of $1 \mathrm{M} \mathrm{NaOH}$, and absorbance at $405 \mathrm{~nm}\left(\mathrm{OD}_{405}\right)$ was then recorded. Relative proteolytic activity was calculated as the ratio of the $\mathrm{OD}_{405} / \mathrm{OD}_{600}$. The experiment was repeated.

The production of extracellular proteases was also assessed on skimmed milk dishes. For this purpose, a volume of $5 \mu \mathrm{l}$ of a cell suspension $\left(\mathrm{OD}_{600}=1\right)$ corresponding to $5 \times 10^{5} \mathrm{CFU}$ for each strain was inoculated onto LBA amended with $1 \%(\mathrm{w} / \mathrm{v})$ of skimmed milk. Once inoculated, Petri dishes were incubated at $28^{\circ} \mathrm{C}$ and the diameter of the clarification halo was measured after 48 h. Five Petri dishes (replicates) were used for each strain and the experiment was repeated.

\section{Kinetics of Cyclic Lipopeptide Production}

The FZB42, S499, and S499 $\mathrm{P}^{-}$strains were grown overnight on LBA at $30^{\circ} \mathrm{C}$ in Petri dishes. Bacterial cells were scraped 
from LBA surface and collected with a loop in $1 \mathrm{ml}$ of sterile distilled $\mathrm{H}_{2} \mathrm{O}$, washed three times in sterile distilled $\mathrm{H}_{2} \mathrm{O}$, and the $\mathrm{OD}_{600}$ was adjusted to 1 . A volume of $1 \mathrm{ml}$ of the deriving cell suspensions was inoculated into Erlenmeyer flasks containing $100 \mathrm{ml}$ of LB broth. Flasks were then incubated for $24 \mathrm{~h}$ at $28^{\circ} \mathrm{C}$ (110 rpm). The samples were collected every hour from 0 to $12 \mathrm{~h}$ with final sampling after $24 \mathrm{~h}$. From each flask, $3 \mathrm{ml}$ of cell culture were transferred to three microfuge tubes ( $1 \mathrm{ml}$ each), which were centrifuged for $5 \mathrm{~min}$ at 12,600 rpm. Supernatants were used for the identification and quantification of cyclic lipopeptides with UPLC-ESI-MS. Cell pellets were stored at $-20^{\circ} \mathrm{C}$ for analysis of gene expression ( $s r f A$ and $r a p$ ) using RNA extraction and quantitative reverse transcription-polymerase chain reaction (qRT-PCR), and measurement of bacterial growth with flow cytometry. The experiment was carried out three times.

Samples were analyzed using reverse phase UPLC (Acquity class H, Waters Corp., USA) coupled with a single quadrupole MS (SQ Detector, Waters Corp.) on an Acquity UPLC BEH C18 $2.1 \times 50 \mathrm{~mm}, 1.7 \mu \mathrm{m}$ column (Waters Corp.). Elution started at $30 \%$ acetonitrile (flow rate of $0.60 \mathrm{ml} \mathrm{min}^{-1}$ ). After $2.43 \mathrm{~min}$, the percentage of acetonitrile was brought up to $95 \%$ and held for 5.2 min. Then, the column was stabilized at $30 \%$ acetonitrile for 1.7 min. Compounds were identified based on their retention times compared to authentic standards (98\% purity; Lipofabrik Society, France) and the masses detected in the SQDetector. Ionization and source conditions were set as follows: source temperature $=$ $130^{\circ} \mathrm{C}$; desolvation temperature $=400^{\circ} \mathrm{C}$; nitrogen flow $=1000 \mathrm{l}$ $\mathrm{h}^{-1}$; cone voltage $=120 \mathrm{~V}$.

\section{Quantification of Relative Gene Expression}

Total RNA was extracted with a NucleoSpin ${ }^{\circledR}$ RNA kit (Macherey-Nagel GmbH \& Co. KG, Germany) according to the manufacturer's instructions. Quantification of srfA and pS499 rap relative gene expression was done using reverse transcription Real-time PCR (StepOnePlus ${ }^{\mathrm{TM}}$, Thermo Fisher Scientific Inc.), with a qPCRBIO SyGreen 1-Step Hi-ROX kit (PCR Biosystems Ltd, UK). Primers used in the reactions were designed by Primer3web version 4.0.0 (Untergasser et al., 2012) and are listed in Table S3. The qRT-PCR program consisted of a first step of 10 min at $48^{\circ} \mathrm{C}$, followed by $2 \mathrm{~min}$ at $95^{\circ} \mathrm{C}$, and 40 cycles in series of $5 \mathrm{~s}$ at $95^{\circ} \mathrm{C}$ and $30 \mathrm{~s}$ at $60^{\circ} \mathrm{C}$. The housekeeping gene $g y r A$ was used as an endogenous control.

The relative gene expression was calculated according to the comparative $\mathrm{C}_{\mathrm{T}}$ method (Livak and Schmittgen, 2001). At each time point, $\Delta \mathrm{C}_{\mathrm{T}}$ was determined by subtracting the threshold cycle $\left(\mathrm{C}_{\mathrm{T}}\right)$ value of gyrA from the $\mathrm{C}_{\mathrm{T}}$ value of the target gene; then the $\Delta \mathrm{C}_{\mathrm{T}}$ of sample "time 0 " was subtracted from the $\Delta \mathrm{C}_{\mathrm{T}}$ values of the following sampling times, obtaining $\Delta \Delta \mathrm{C}_{\mathrm{T}}$ values. Finally, the relative quantity (RQ) of gene expression was calculated according to this formula:

$$
\mathrm{RQ}=2^{-\Delta \Delta \mathrm{CT}}
$$

\section{Measurement of Bacterial Growth with Flow Cytometry}

A first sonication step was used to dissolve cellular aggregates. Cell pellets were suspended in $500 \mu \mathrm{l}$ of staining solution S1
(72 $\mathrm{g} \mathrm{l}^{-1}$ tartaric acid; $3.89 \mathrm{~g} \mathrm{l}^{-1} \mathrm{Na}_{2} \mathrm{HPO}_{4} ; 2.85 \mathrm{~g} \mathrm{l}^{-1}$ EDTA; $0.0375 \mathrm{~g} \mathrm{l}^{-1}$ sucrose monohydrate; $\mathrm{pH} 3$ ) over three cycles of gentle sonication (15-20s at $25-30 \%$ of the power of the device, Sonopuls HD 2070, Bandelin GmbH, Germany). Subsequently, $500 \mu \mathrm{l}$ of solution S2 (1.95 $\mathrm{g} \mathrm{l}^{-1}$ citric acid; $5.8 \mathrm{~g} \mathrm{l}^{-1} \mathrm{NaCl} ; 1.45 \mathrm{~g}$ $1^{-1} \mathrm{Na}_{2} \mathrm{HPO}_{4}$; $\mathrm{pH} 3.8$ ) supplied with $0.2 \%$ acridine orange were added. Samples were then mixed by vortexing thoroughly, before being analyzed with flow cytometry (BD Accuri ${ }^{\mathrm{TM}}$ C6, Becton, Dickinson and Company, USA) for cell counting.

\section{Swarming Motility and Biofilm Formation}

The swarming motility of FZB42, S499, and S499 $\mathrm{P}^{-}$was evaluated according to Pertot et al. (2013). The diameter of the bacterial macrocolonies was measured at 12, 16, and $20 \mathrm{~h}$ after inoculation. Four Petri dishes (replicates) were used for each strain and the experiment was repeated.

The production of biofilm by FZB42, S499, and S499 $\mathrm{P}^{-}$in 24well polystyrene plates was determined according to Pertot et al. (2013). Specific biofilm formation (SBF) was calculated according to Yaryura et al. (2008) with the following formula:

$$
\mathrm{SBF}=(\mathrm{B}-\mathrm{NC}) / \mathrm{BG}
$$

where $B$ is the amount of crystal violet attached to the well surfaces measured at $590 \mathrm{~nm}\left(\mathrm{OD}_{590}\right), \mathrm{NC}$ is the $\mathrm{OD}_{590}$ of the negative control and BG is the bacterial growth measured at 600 $\mathrm{nm}\left(\mathrm{OD}_{600}\right)$. Eight wells (replicates) were used for each strain and the experiment was repeated.

\section{Antagonism against Fungal Phytopathogens}

The antifungal activity of FZB42, S499, and S499 $\mathrm{P}^{-}$was tested against Cladosporium cucumerinum and Fusarium oxysporum f. sp. radicis-lycopersici. Cladosporium cucumerinum was streaked over the whole LBA surface in Petri dishes, and subsequently a volume of $5 \mu \mathrm{l}$ of bacterial cell suspension $\left(\mathrm{OD}_{600}=1\right)$ corresponding to $5 \times 10^{5} \mathrm{CFU}$ was inoculated onto it. Petri dishes were incubated at $28^{\circ} \mathrm{C}$ for $72 \mathrm{~h}$. To test for F. oxysporum f. sp. radicis-lycopersici, bacterial cells were inoculated onto LBA, $2 \mathrm{~cm}$ from the edge of the Petri dishes. Once inoculated, dishes were incubated at $28^{\circ} \mathrm{C}$ for $72 \mathrm{~h}$. Plugs of F. oxysporum f. sp. radicis-lycopersici mycelium $(5 \mathrm{~mm})$ were cut away from the edge of young (5-day-old) colonies grown on PDA and placed 2.5 $\mathrm{cm}$ from the bacterial colonies. Petri dishes were incubated at $28^{\circ} \mathrm{C}$ for $72 \mathrm{~h}$. Dishes not inoculated with the bacterial strains were used as a control. At the end of the incubation period, the inhibition zone (distance between bacterial colonies and mycelia) was measured. Moreover, two plugs ( $5 \mathrm{~mm}$ ) of medium were removed from the inhibition zone and transferred to 1.5 $\mathrm{ml}$ microfuge tubes containing $1 \mathrm{ml}$ of $50 \%$ acetonitrile and $0.1 \%$ formic acid. Cyclic lipopeptides were extracted by regular vortexing for $2 \mathrm{~h}$ at room temperature. Then, samples were centrifuged and filtered through a $0.2 \mu \mathrm{m}$ membrane (Sartorius AG) before being injected into UPLC-ESI-MS columns according to the procedure reported above. Three dishes were used for each combination (replicates) and the experiment was repeated. 


\section{Statistical Analysis}

As the $F$-test $(\alpha=0.05)$ revealed non-significant differences between repeated experiments $(p>0.5)$, the data were pooled. For proteolytic activity, CLP production, swarming motility, and biofilm formation assays, data were subjected to one-way ANOVA. The data obtained in the antagonism experiments were subjected to multifactorial ANOVA. Tukey's test $(\alpha=0.05)$ was used to perform mean pairwise comparisons. Statistical analysis was carried out using Excel (Microsoft Corp., USA) and Statistica (Dell Inc., USA).

\section{RESULTS}

\section{Specific Genetic Traits of the Bacillus amyloliquefaciens subsp. plantarum S499 Chromosome}

Comparative genomics first confirmed that $\mathrm{S} 499$ belongs to the taxonomic group of the B. amyloliquefaciens subsp. plantarum. Indeed, its genome shares the highest level of sequence similarity with the NJN-6, JJ-D34, CAU B946, and B25 strains, forming a subclade of the branch including FZB42 and all other strains classified under the "plantarum" subspecies. This branch is separated from those of the closely related $B$. amyloliquefaciens subsp. amyloliquefaciens DSM7, B. subtilis subsp. subtilis 168, and B. licheniformis ATCC 14580 (Figure 1). However, comparison of general genomic features (genome size, $\mathrm{G}+\mathrm{C}$ content, the number of coding sequences, RNA operons, tRNAs, and insertion sequence elements) showed high similarity with these species. A significant difference emerged in the content of phage-related genes. Indeed, the S499 genome has 154 phage-related genes, while only 44 and 71 of these genes are present in the FZB42 and B. licheniformis ATCC 14580 genomes, respectively. However, the phage-related gene content in the $\$ 499$ genome is lower than that of B. amyloliquefaciens subsp. amyloliquefaciens DSM7 (273 genes) and B. subtilis subsp. subtilis 168 (268 genes) (Table 1).

Assembly of the $\mathrm{S} 499$ genome sequence revealed that its chromosome has a different arrangement, including a large inversion compared to the FZB42 genome (Figure 2A). Alignment against the FZB42 genome showed 98\% of nucleotide identity out of $94 \%$ query cover (Figure 2B). The S499 genome shares 46 and $88 \%$ of coding sequences (CDS), with respectively $>99 \%$ and $>90 \%$ identity at amino acid level with the FZB42 genome. Their core genomes include 3547 CDS. As

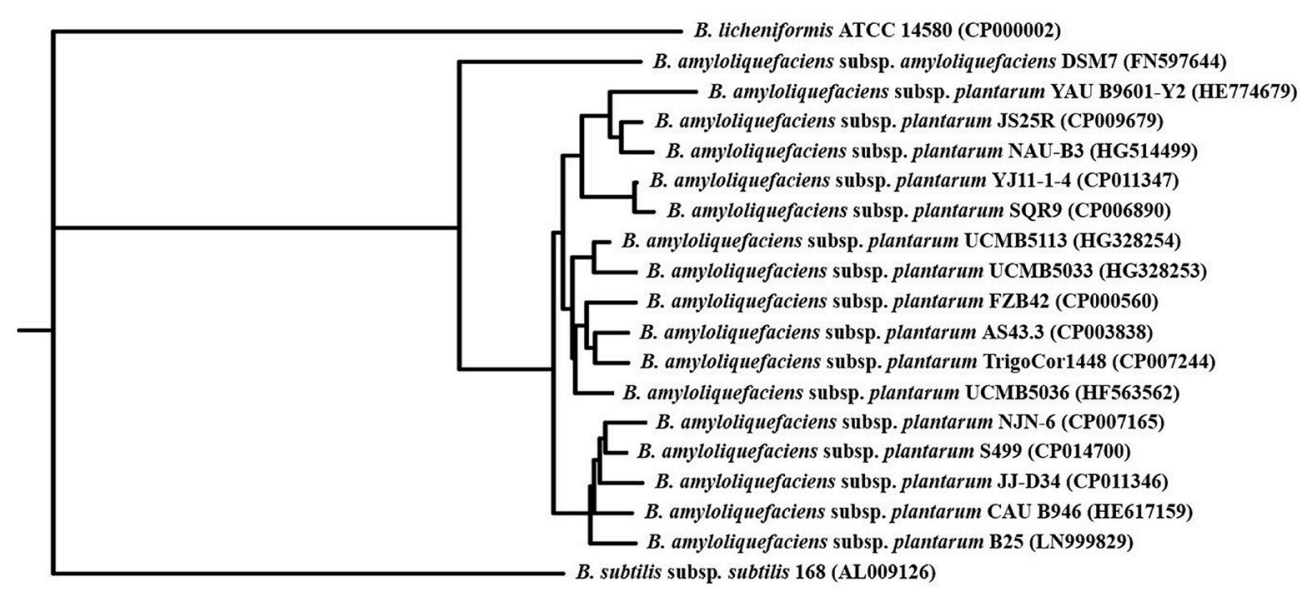

FIGURE 1 | Phylogenetic tree of Bacillus amyloliquefaciens subsp. plantarum. The Neighbor-Joining phylogenetic tree was obtained with PHYLIP applications after fragmented all-against-all comparison performed using Gegenees software 2.2.1 with the complete genome sequences of 19 strains belonging to the Bacillus genus (accession numbers are reported in brackets).

TABLE 1 | Principal genomic features of Bacillus amyloliquefaciens subsp. plantarum S499, in comparison with the genomes of the closely related Bacillus spp.

\begin{tabular}{|c|c|c|c|c|c|}
\hline & $\begin{array}{l}\text { B. amyloliquefaciens } \\
\text { subsp. plantarum S499 }\end{array}$ & $\begin{array}{c}\text { B. amyloliquefaciens } \\
\text { subsp. plantarum FZB42 }\end{array}$ & $\begin{array}{l}\text { B. amyloliquefaciens subsp. } \\
\text { amyloliquefaciens DSM7 }\end{array}$ & $\begin{array}{l}\text { B. subtilis subsp. } \\
\text { subtilis } 168\end{array}$ & $\begin{array}{l}\text { B. licheniformis } \\
\text { ATCC } 14580\end{array}$ \\
\hline Genome size (bp) & $3,927,922$ & $3,918,589$ & $3,980,199$ & $4,214,814$ & $4,222,645$ \\
\hline $\mathrm{G}+\mathrm{C}$ contents $(\%)$ & 46.6 & 46.4 & 46.1 & 43.5 & 46.2 \\
\hline Coding sequences (CDS) & 3974 & 3863 & 3924 & 4114 & 4199 \\
\hline Ribosomal RNA operons & 8 & 10 & 10 & 10 & 7 \\
\hline Number of tRNAs & 81 & 89 & 94 & 86 & 72 \\
\hline Plasmids & 1 & - & - & - & - \\
\hline Insertion sequence elements & 1 & 9 & 18 & - & 10 \\
\hline Phage-associated genes & 154 & 44 & 273 & 268 & 71 \\
\hline
\end{tabular}


A

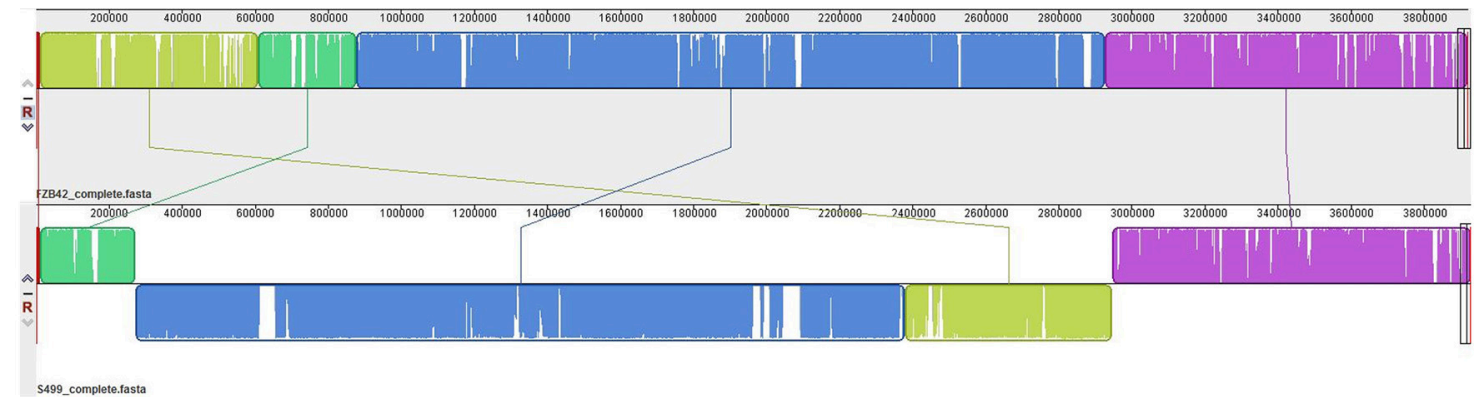

B

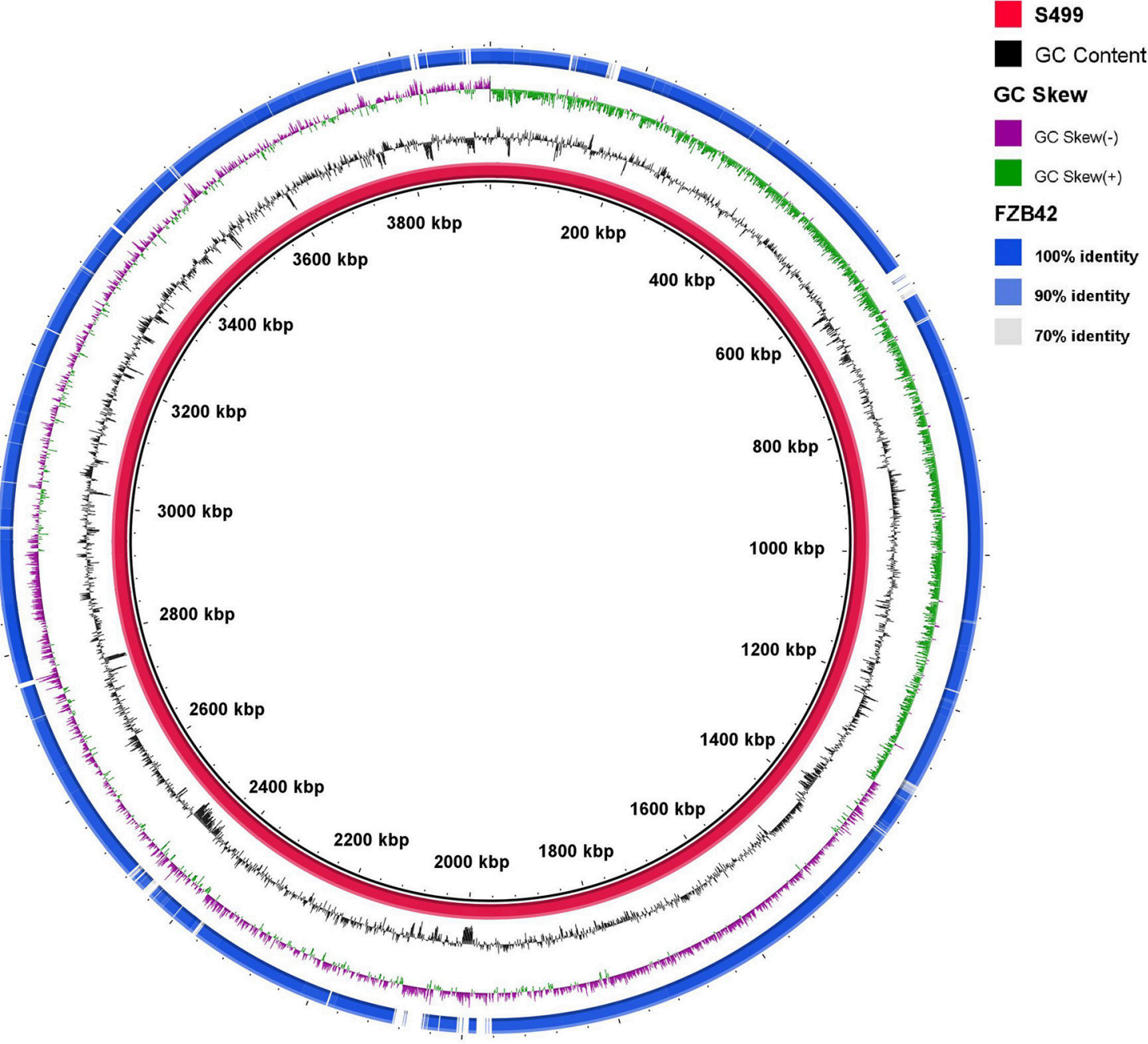

FIGURE 2 | Whole-genome comparison between the Bacillus amyloliquefaciens subsp. plantarum S499 and Bacillus amyloliquefaciens subsp. plantarum FZB42 genomes. (A) MAUVE alignment shows genomic rearrangement of the S499 genome compared to the FZB42 chromosome. (B) BRIG alignment of the S499 and FZB42 genomes. From inner to outer ring: (1) nucleotide sequence of the S499 genome; (2) GC percent; (3) GC skew; (4) Blast comparison with the FZB42 genome.

regards homologous genes with functions related to rhizosphere competence, plant-growth promotion and antimicrobial activity, nucleotide identity is always above $95 \%$, with one case of $100 \%$ sequence identity for the $a b r B$ gene (Table 2).
A large number (46\%) of S499 CDS not shared with FZB42 are annotated as hypothetical proteins, whereas 30\% are phage-related genes. Moreover, genes putatively involved in primary metabolism (10\%), transcriptional regulation $(4 \%)$, 
TABLE 2 | Genes involved in root colonization, plant growth promotion and biocontrol common to Bacillus amyloliquefaciens subsp. plantarum S499 and Bacillus amyloliquefaciens subsp. plantarum FZB42 (sequence similarity is expressed as the percentage of nucleotide identity).

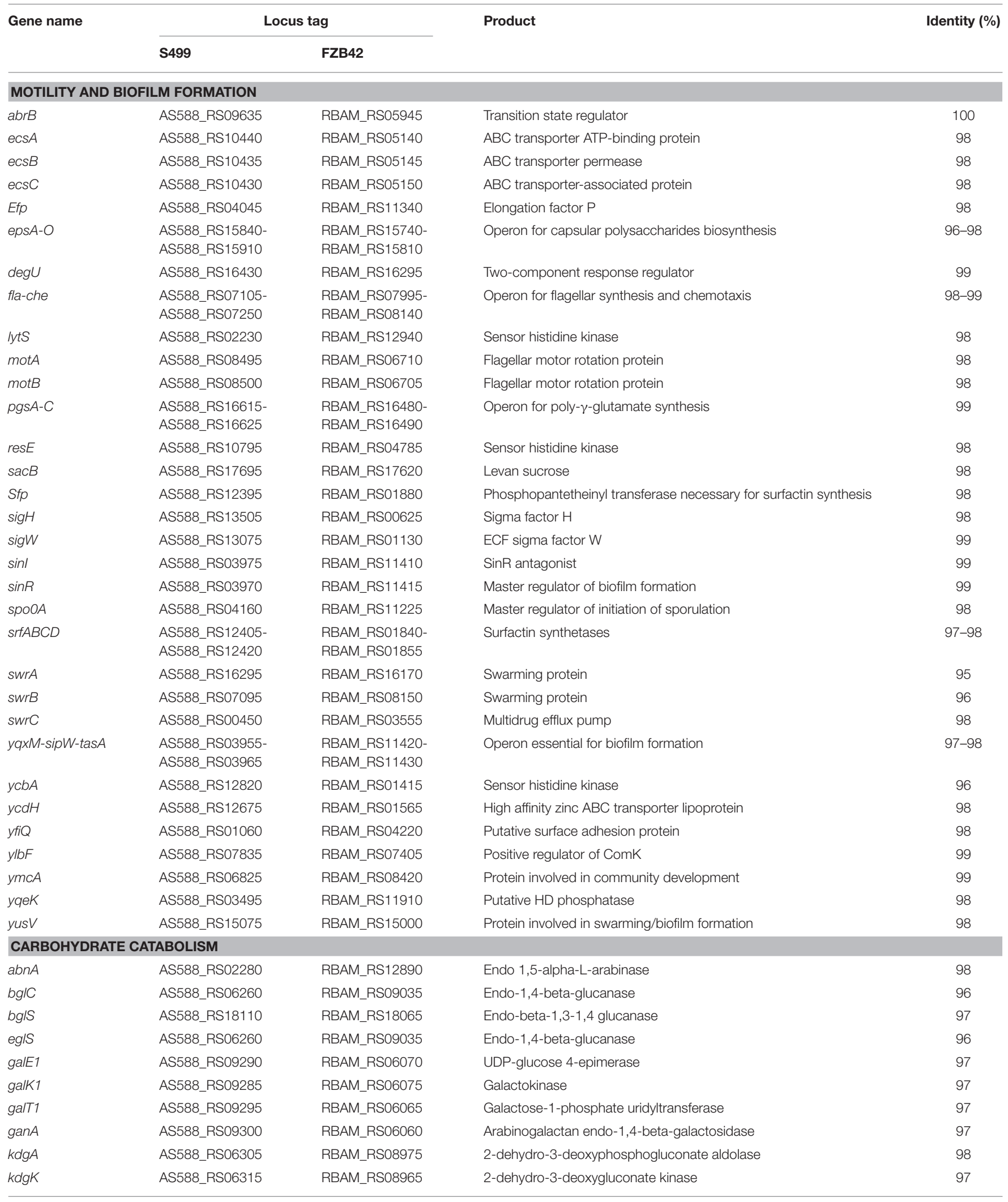


TABLE 2 | Continued

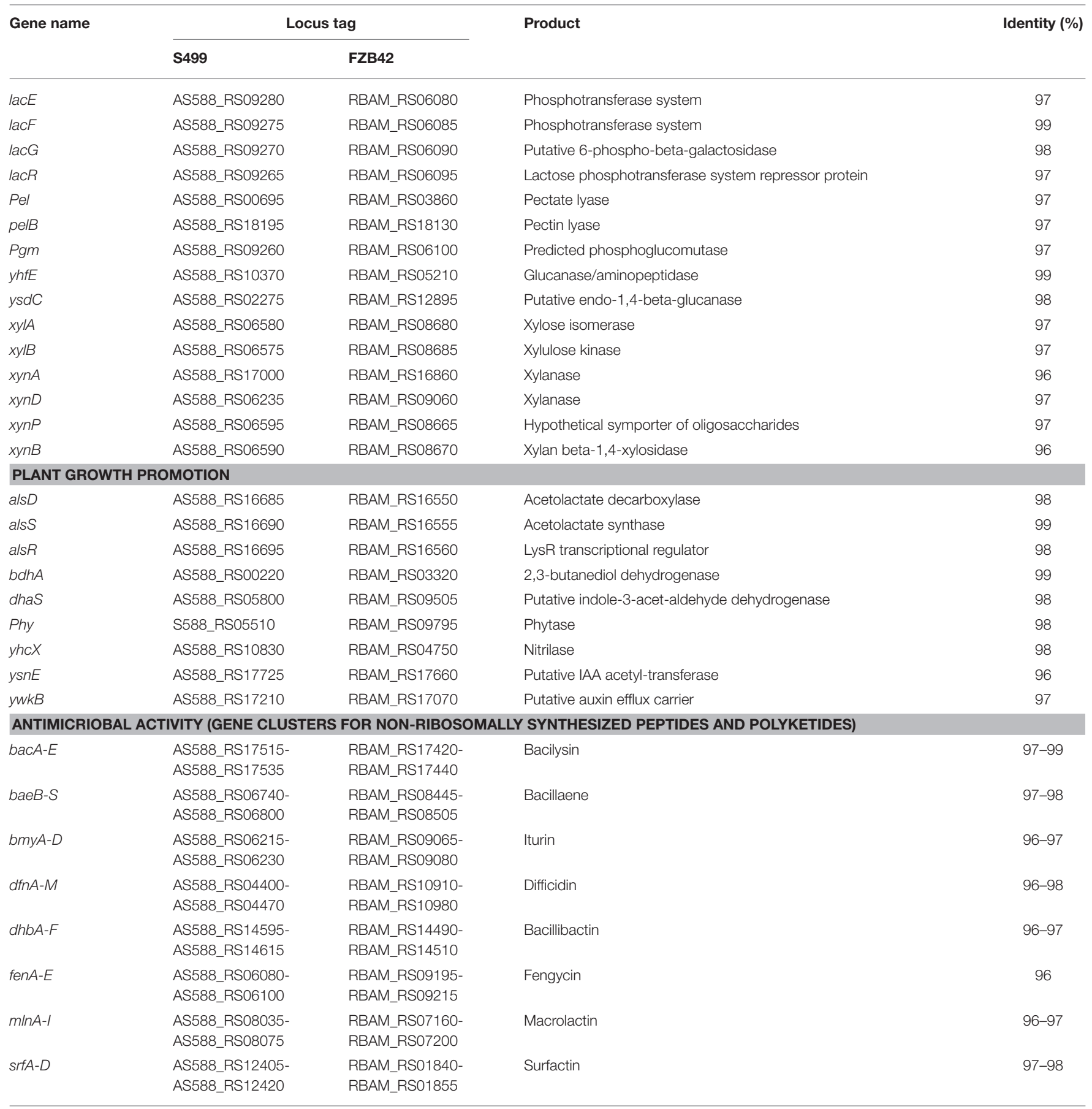

transport systems (2\%), tetracycline resistance, and lanthionine biosynthesis are included in the remaining unique S499 CDS. Similarly to S499, a considerable number of FZB42 unique CDS (44\%) are also classified as hypothetical proteins. However, among function-annotated CDS there are ribosomal genes (12\%), genes encoding enzymes involved in transport, and detoxification (6\%), genes related to restriction systems (5\%), transcriptional regulation (3\%), and acriflavine resistance (Table S4).

\section{A Rare Plasmid Is Present in the Genome of Bacillus amyloliquefaciens subsp. plantarum S499}

An additional important genetic feature distinguishing S499 from FZB42 is the presence of plasmid DNA (8008 bp). Based on the plasmid:chromosome sequence coverage ratio, we estimate that there are at least two copies of this plasmid (pS499) per cell. The few genes located on pS499 (Figure 3) 


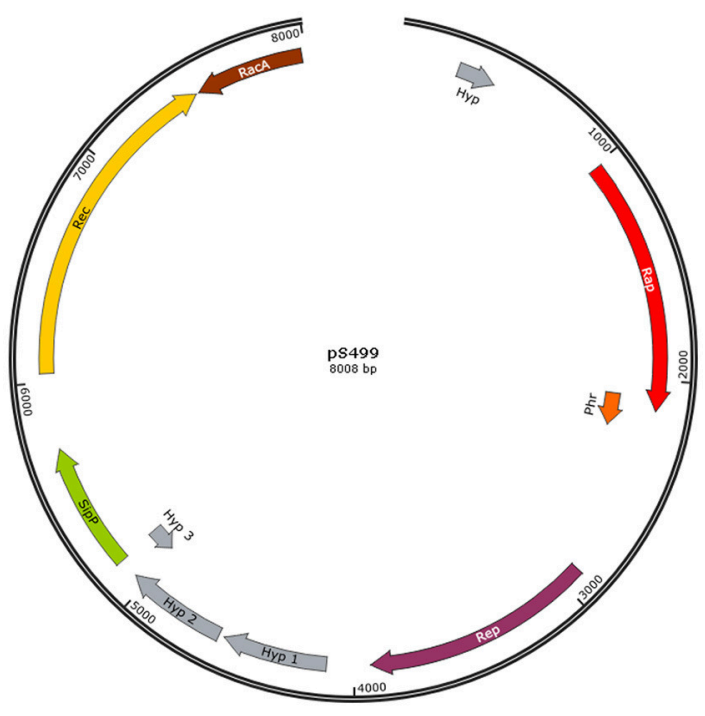

FIGURE 3 | Graphic representation of plasmid pS499 from Bacillus amyloliquefaciens subsp. plantarum S499. Structure of plasmid pS499 according to PROKKA annotations (Hyp, hypothetical protein; Rap, response regulator aspartate phosphatase; Phr, phosphate regulator peptide; Rep, replication protein; SipP, signal peptidase I P; Rec, recombination protein; RacA, chromosome-anchoring protein).

encode proteins involved in replication (AS588_19065, Rep) and mobilization (AS588_19090, Rac; AS588_19095, RecA) of the plasmid, a signal peptidase (AS588_19085, SipP), and a response regulator aspartate phosphatase (AS588_19060, Rap). Moreover, we identified a plasmid region encoding the putative Rap regulatory peptide (Phr) located downstream of the rap gene. In addition to this plasmid rap-phr cassette, nine genes encoding different members of the Rap family are located on the chromosome of S499. Seven of these genes show 98$99 \%$ nucleotide identity with the homologous genes of FZB42 (Table 3).

Comparison of the 32 available genome sequences of other B. amyloliquefaciens subsp. plantarum strains revealed that three of them (JS25R, NAU-B3, B25) have a plasmid of similar size also containing a rap sequence (Table 4). The rap genes encoded by the plasmids of JS25R (CP009680, 8438 bp) and NAU-B3 (HG514500, 8439 bp) showed 99\% identity with the rap gene of pS499 at nucleotide level. In contrast, the rap gene located on the plasmid of B25 (LN999830, 8138 bp) does not share homology with that located on pS499. However, the B25 Rap protein shows $47 \%$ identity with the chromosome-encoded RapI of S499 at amino acid level.

The very low occurrence of a plasmid similar to pS499 also extends to the taxon B. amyloliquefaciens subsp. amyloliquefaciens, where only 2 out of 36 strains possess a plasmid. Specifically, the plasmid of strain MBE1283 (CP013728, $13,003 \mathrm{bp}$ ) has no rap genes, while the plasmid of strain LL3 (CP002635, $6758 \mathrm{bp}$ ) includes a rap gene that is not homologous to the one encoded by pS499 (Table 4) even if it shares $38 \%$ identity with the $\$ 499$ chromosome-encoded RapI at amino acid level.
TABLE 3 | Genes encoding Rap proteins identified in the genome of Bacillus amyloliquefaciens subsp. plantarum S499 and sequence similarity with the homologous genes of Bacillus amyloliquefaciens subsp. plantarum FZB42.

\begin{tabular}{|c|c|c|c|c|}
\hline \multirow{2}{*}{$\begin{array}{l}\text { Gene } \\
\text { name }\end{array}$} & \multicolumn{2}{|c|}{ Locus tag } & \multirow[t]{2}{*}{ Product } & \multirow{2}{*}{$\begin{array}{c}\text { Identity at } \\
\text { nucleotide } \\
\text { level (\%) }\end{array}$} \\
\hline & S499 & FZB42 & & \\
\hline \multicolumn{5}{|c|}{ CHROMOSOME } \\
\hline rapA_2 & AS588_RS09075 & RBAM_RS06230 & RapA & 99 \\
\hline rapl_1 & AS588_RS11695 & - & Rapl & - \\
\hline$r a p F_{-} 1$ & AS588_RS12260 & RBAM_RS02015 & RapF/RapC & 99 \\
\hline rapJ & AS588_RS12690 & RBAM_RS01550 & RapJ & 99 \\
\hline $\mathrm{rapH}$ & AS588_RS14175 & RBAM_RS02305 & $\mathrm{RapH}$ & 53 \\
\hline rapF_2 & AS588_RS16895 & RBAM_RS16755 & RapF & 98 \\
\hline rapA_4 & AS588_RS17040 & RBAM_RS16900 & RapA/RapB & 99 \\
\hline rapF_3 & AS588_RS17360 & RBAM_RS17235 & RapF & 98 \\
\hline rapl_3 & AS588_RS18595 & RBAM_RS18570 & Rapl/RapX & 98 \\
\hline \multicolumn{5}{|c|}{ PLASMID } \\
\hline rapA_5 & AS588_19060 & - & RapA/RapQ & - \\
\hline
\end{tabular}

In B. subtilis, out of 11 small plasmids (ranging from 2246 to 8737 bp), only two (pTA1040, 7837 bp, and pTA1060, 8737 bp) include rap sequences (rap40 and rap60) displaying respectively 65 and $71 \%$ identity with the rap gene of pS499 at nucleotide level (Table 4). Other rap genes encoded by bigger plasmids (75-85 $\mathrm{Kb})$ do not show identity with the rap gene of pS499.

In addition, we were also able to rule out the presence of analogous plasmids in six other Bacillus spp. strains from our lab collection $(23,76,98 \mathrm{R}, 98 \mathrm{~S}, 104, \mathrm{GA} 1)$, since no bands were observed in gel electrophoresis after plasmid DNA extraction and no pS499 rap gene was amplified by PCR (data not shown).

\section{The Presence of Plasmid PS499 Affects Growth Kinetics and Proteolytic Activity}

An S499 colony that had lost the plasmid was isolated after 14 culture cycles in sub-inhibitory conditions. On LBA, the colonies of the cured strain, named S499 $\mathrm{P}^{-}$, were morphologically different and more precisely, smoother, and larger compared to colonies of the wild-type S499. The 16S rDNA and the sequences of gyrA and cheA genes of S499 $\mathrm{P}^{-}$were amplified, sequenced, and aligned to the respective sequences of S499 to prove that S499 $\mathrm{P}^{-}$was a derivative of S499. For each gene, the PCR products shared 100\% nucleotide sequence identity (Supplementary Data Sheet).

Following cultivation in LB broth, the growth dynamics of S499 $\mathrm{P}^{-}$clearly differed from the parental strain and were actually more similar to the kinetics observed for FZB42, with a reduced lag phase and an increased growth rate. The logarithmic phase lasted $5.3 \pm 0.2 \mathrm{~h}$ (average \pm standard error) for S499 $\mathrm{P}^{-}$, while for S499 and FZB42 it lasted $6.3 \pm 0.3 \mathrm{~h}$ and $6.3 \pm$ $0.2 \mathrm{~h}$ respectively. However, $\mathrm{S} 499 \mathrm{P}^{-}$had a lower final $\mathrm{OD}_{600}$ compared to S499 and FZB42 (Figure 4, black lines). Given these trends, we tested whether the faster cellular growth of S499 $\mathrm{P}^{-}$could be linked to higher proteolytic activity, liberating amino acids as substrates from the proteinaceous source. First, 
TABLE 4 | Plasmids similar to pS499 present in Bacillus amyloliquefaciens and Bacillus subtilis strains.

\begin{tabular}{|c|c|c|c|c|}
\hline Strain & Plasmid name & Plasmid (accession number) & Rap gene (locus tag) & Identity (\%) \\
\hline B. amyloliquefaciens subsp. plantarum JS25R & pBMJS25R & CP009680 & NG74_RS19355 & 99 \\
\hline B. amyloliquefaciens subsp. plantarum NAU-B3 & pBAMMD1 & HG514500 & BAPNAU_RS20545 & 99 \\
\hline B. amyloliquefaciens subsp. plantarum B25 & $\|$ & LN999830 & BAMMD1_RS18490 & - \\
\hline B. amyloliquefaciens subsp. amyloliquefaciens LL3 & $\mathrm{pMC1}$ & CP002635 & LL3_RS20265 & - \\
\hline B. subtilis IAM 1232 & pTA1040 & NC_001764 & pTA1040_p6 & 65 \\
\hline B. subtilis IFO 3022 & pTA1060 & NC_001766 & pTA1060_p7 & 71 \\
\hline
\end{tabular}

The plasmids harboring a rap gene are reported in the table (sequence similarity with the pS499 gene is expressed as the percentage of nucleotide identity).

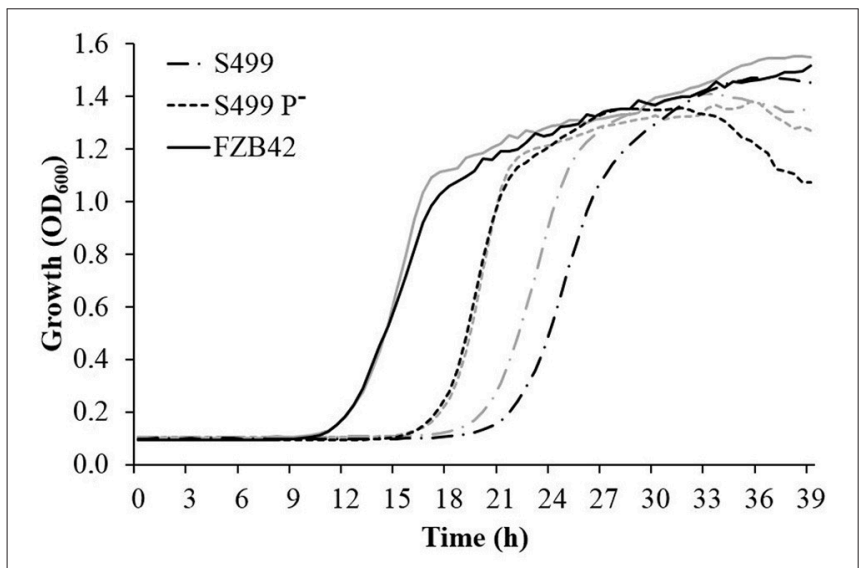

FIGURE 4 | Effects of plasmid curing and medium composition on bacterial growth. Bacillus amyloliquefaciens subsp. plantarum FZB42, S499 and its plasmid-cured derivative, S499 $\mathrm{P}^{-}$, were grown in LB broth (black lines) and modified LB broth (gray lines) at $28^{\circ} \mathrm{C}$. The assays were carried out in 48-well plates, and optical density at $600 \mathrm{~nm}\left(\mathrm{OD}_{600}\right)$ was read every 30 min. Reported $\mathrm{OD}_{600}$ values correspond to the averages of reads from three different wells in one representative experiment.

we observed that substitution of tryptone by casamino acids in LB broth did not affect the cell growth of FZB42 and S499 $\mathrm{P}^{-}$, whereas it led to faster entry in the logarithmic phase in S499 (Figure 4, gray lines). The hypothesis of higher proteolytic activity of S499 $\mathrm{P}^{-}$compared to S449 was then confirmed by testing the size of clarification halos forming around the colonies on LBA amended with skimmed milk. Indeed, after $48 \mathrm{~h}$ of incubation, the clarification halo around S499 $\mathrm{P}^{-}(3.0 \pm 0.2$ $\mathrm{mm}$; average \pm standard error) was larger than that of S499 (1.4 $\pm 0.3 \mathrm{~mm}$ ), but smaller than the halo around FZB42 colonies $(4.7 \pm 0.4 \mathrm{~mm})$ (Figure 5). These results were also supported by the fact that, after $6 \mathrm{~h}$ growth in LB medium, the release of extracellular proteases was greater in S499 $\mathrm{P}^{-}$than in the wild type, determining slightly higher digestion of azocasein (Figure S1).

\section{Plasmid PS499 Influences Lipopeptide Production}

UPLC-ESI-MS analysis of culture filtrates at the end of the bacterial growth revealed that $S 499 \mathrm{P}^{-}$produced more surfactins (120.35 $\pm 8.29 \mu \mathrm{g} \mathrm{ml}^{-1}$, average \pm standard error) and fengycins

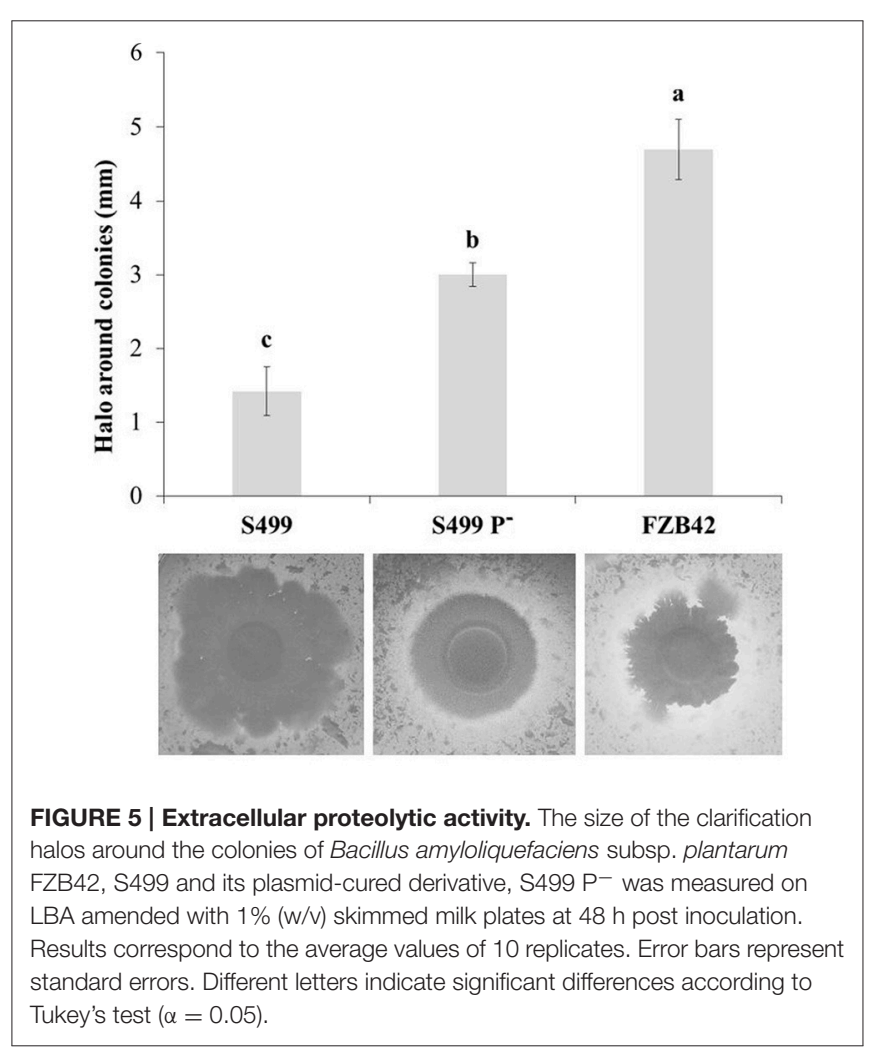

$\left(39.60 \pm 7.41 \mu \mathrm{g} \mathrm{ml}^{-1}\right)$, but fewer iturins $(32.30 \pm 10.08 \mu \mathrm{g}$ $\left.\mathrm{ml}^{-1}\right)$ than $\mathrm{S} 499\left(95.54 \pm 1.33 \mu \mathrm{g} \mathrm{ml}^{-1}, 22.29 \pm 7.02 \mu \mathrm{g}\right.$ $\mathrm{ml}^{-1}$ and $56.65 \pm 13.99 \mu \mathrm{g} \mathrm{ml}^{-1}$, respectively), although not significantly. FZB42 instead produced many more fengycins $\left(238.10 \pm 14.43 \mu \mathrm{g} \mathrm{ml}^{-1}\right)$ and iturins $\left(211.05 \pm 24.01 \mu \mathrm{g} \mathrm{ml}^{-1}\right)$, but fewer surfactins $\left(84.10 \pm 7.05 \mu \mathrm{g} \mathrm{ml}^{-1}\right)$ than S499 and S499 $\mathrm{P}^{-}$(Figure S2).

To better understand the role of the plasmid in CLP production, we set up a new growth assay that allowed us to follow the kinetics of production during culture. In line with the $\mathrm{OD}_{600}$ results, CFU counts indicated that $\mathrm{S} 499 \mathrm{P}^{-}$grew faster than S499, showing significant differences compared to the growth curve of S499 at 11 and $12 \mathrm{~h}$, but not differently from FZB42 in these conditions (Figure 6A). The production of surfactins by S499 $\mathrm{P}^{-}$, similarly to FZB42, started earlier compared to $\mathrm{S} 499$, resulting in a significant increase in surfactin 

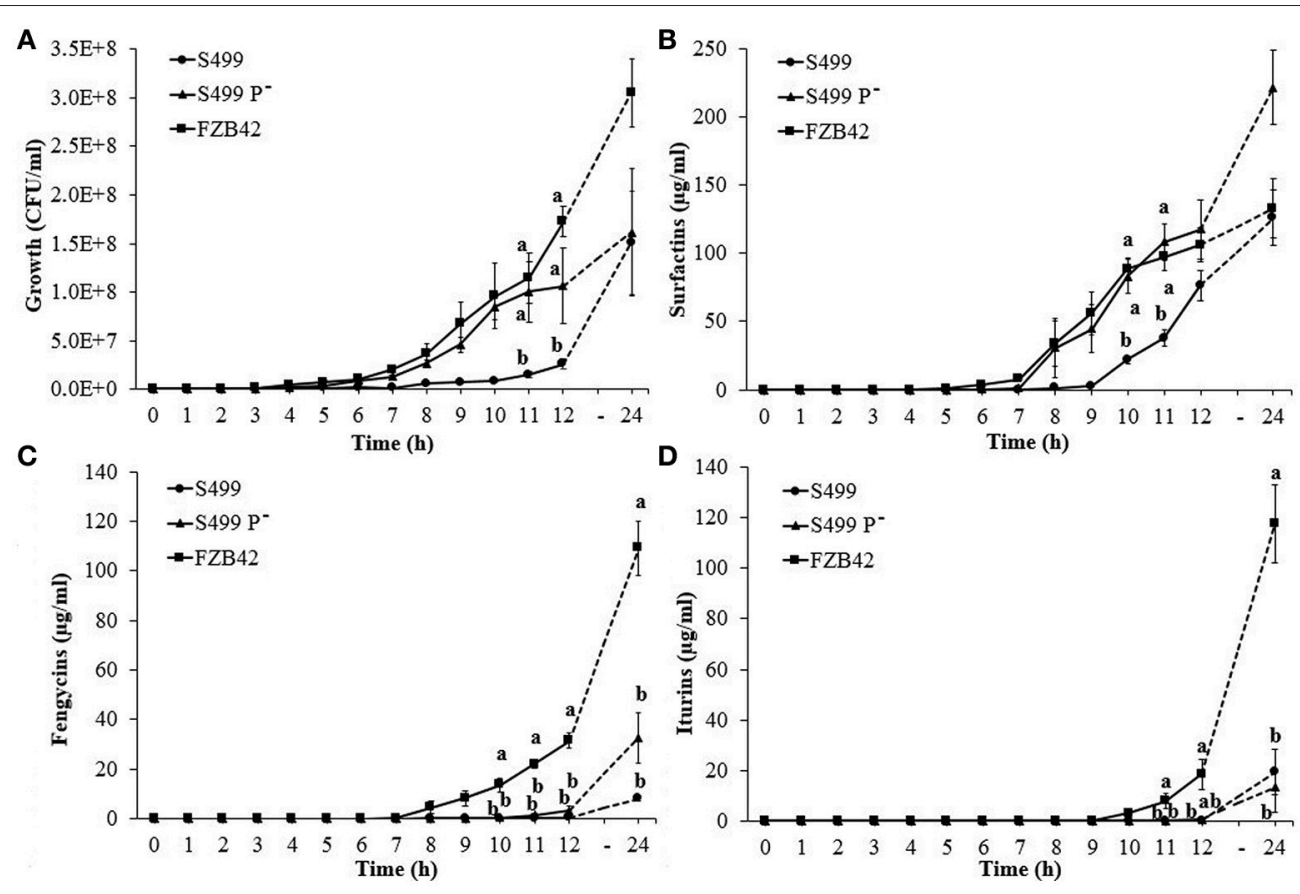

FIGURE 6 | Kinetics of cyclic lipopeptide production. Growth curves (A) and surfactin (B), fengycin (C), and iturin (D) production in Bacillus amyloliquefaciens subsp. plantarum FZB42, S499 and its plasmid-cured derivative, S499 $\mathrm{P}^{-}$. Values correspond to the resulting averages of standardized data $\left[Z=(X / \mu)^{*} 100\right]$ from three independent experiments. Error bars represent standard errors and different letters indicate significant differences according to Tukey's test ( $\alpha=0.05)$.

concentrations measured after 10 and $11 \mathrm{~h}$ of incubation. At 12 $\mathrm{h}, \mathrm{S} 499 \mathrm{P}^{-}$and FZB42 had released $118 \pm 21 \mu \mathrm{g} \mathrm{ml}^{-1}$ (average \pm standard error) and $106 \pm 12 \mu \mathrm{g} \mathrm{ml}^{-1}$ of surfactins respectively, while S499 produced only $76 \pm 11 \mu \mathrm{g} \mathrm{ml}^{-1}$. At the final timepoint $(24 \mathrm{~h})$, the trend for surfactin production by S499 $\mathrm{P}^{-}(222$ $\left.\pm 27 \mu \mathrm{g} \mathrm{ml}^{-1}\right)$ was also higher than for FZB42 (133 $\pm 22 \mu \mathrm{g}$ $\mathrm{ml}^{-1}$ ), although not significantly (Figure 6B).

Surfactins were detected in the culture filtrates of the three strains $3 \mathrm{~h}$ after srfA gene expression started to increase. Regression analysis of surfactin production and $s r f A$ gene expression levels assessed $3 \mathrm{~h}$ before was highly significant $\left(p<0.01, y=1.7059 x+15.624, R^{2}=0.283\right)$. In accordance with surfactin production rates, srfA gene expression in $\mathrm{S} 499 \mathrm{P}^{-}$and FZB42 increased earlier than in S499. Specifically, transcription levels of the $s r f A$ gene increased after $5 \mathrm{~h}$ of incubation and production started after $8 \mathrm{~h}$ in FZB42 and S499 $\mathrm{P}^{-}$, whereas in $\mathrm{S} 499$ gene expression increased after $7 \mathrm{~h}$ and surfactins were detected after $10 \mathrm{~h}$ (Figure S3). When the expression of the plasmid-encoded rap gene was assessed in S499, its transcripts were detected at similar level of gyrA gene expression during early $\left(\Delta \mathrm{C}_{\mathrm{T}}=-0.69 \pm 0.66\right.$; average \pm standard error $)$, middle $\left(\Delta \mathrm{C}_{\mathrm{T}}\right.$ $=0.61 \pm 0.65)$ and late growth phases $\left(\Delta \mathrm{C}_{\mathrm{T}}=1.80 \pm 1.12\right)$.

Kinetic tests showed no significant differences in the production of fengycins (detected from $10 \mathrm{~h}$ after incubation) in S499 (0.04 $\pm 0.03 \mu \mathrm{g} \mathrm{ml}^{-1}$, average \pm standard error) and S499 $\mathrm{P}^{-}\left(0.55 \pm 0.18 \mu \mathrm{g} \mathrm{ml}^{-1}\right)$, and production was significantly lower than in FZB42 $\left(13.53 \pm 2.70 \mu \mathrm{g} \mathrm{ml}^{-1}\right)$ (Figure 6C). Similar behavior was observed for iturins, which were only detected in the culture filtrates of S499 and S499 $\mathrm{P}^{-}$starting from $12 \mathrm{~h}$ after incubation, and in lower quantities $(0.10 \pm 0.08$ and 0.70 $\pm 0.43 \mu \mathrm{g} \mathrm{ml}^{-1}$ ) compared to the amounts detected in FZB42 supernatants $\left(18.49 \pm 5.85 \mu \mathrm{g} \mathrm{ml}^{-1}\right.$ ) (Figure 6D). However, at the end of the experiment $(24 \mathrm{~h})$ we observed an increasing although not significant trend for the production of fengycins and lower production of iturins by S499 $\mathrm{P}^{-}$compared to S499, in accordance with previous assays.

\section{The Impact of Plasmid PS499 on Motility and Biofilm Formation}

Given the key role of surfactin in motility and biofilm formation in Bacillus (Raaijmakers et al., 2010), earlier and more abundant release of this CLP by S499 $\mathrm{P}^{-}$could have an impact on these two phenotypic traits. Indeed, after $12 \mathrm{~h}$ of incubation, the diameter of S499 $\mathrm{P}^{-}$macrocolonies $(27.3 \pm 0.2 \mathrm{~mm}$, average \pm standard error) was significantly larger than that observed for the parental strain $(18.3 \pm 0.4)$. The difference between S499 $\mathrm{P}^{-}$and S499 was retained during the experiment, with their colonies measuring $67.0 \pm 0.6 \mathrm{~mm}$ and $55.5 \pm 1.5 \mathrm{~mm}$ respectively after $16 \mathrm{~h}$. On the other hand, FZB42 was significantly faster than both S499 $\mathrm{P}^{-}$ and S499. Indeed, its average macrocolony diameter was $46.5 \pm$ $0.4 \mathrm{~mm}$ after $12 \mathrm{~h}$ of incubation, and the colonies already reached the edge of the dishes after $16 \mathrm{~h}$. After $20 \mathrm{~h}$ of incubation, the surface of each dish was fully covered by the bacterial cells for all strains (Figure 7A).

Conversely, the ability to form biofilm was reduced in S499 $\mathrm{P}^{-}$compared to both S499 and FZB42. Indeed, after $72 \mathrm{~h}$ of static incubation, the SBF values of S499 $\mathrm{P}^{-}(1.51 \pm 0.12$, average \pm standard error) were significantly lower compared to S499 (2.14 


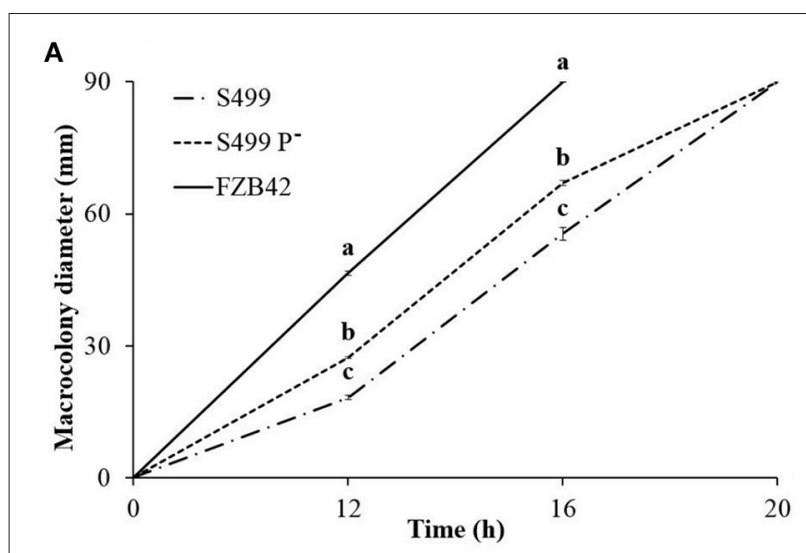

B

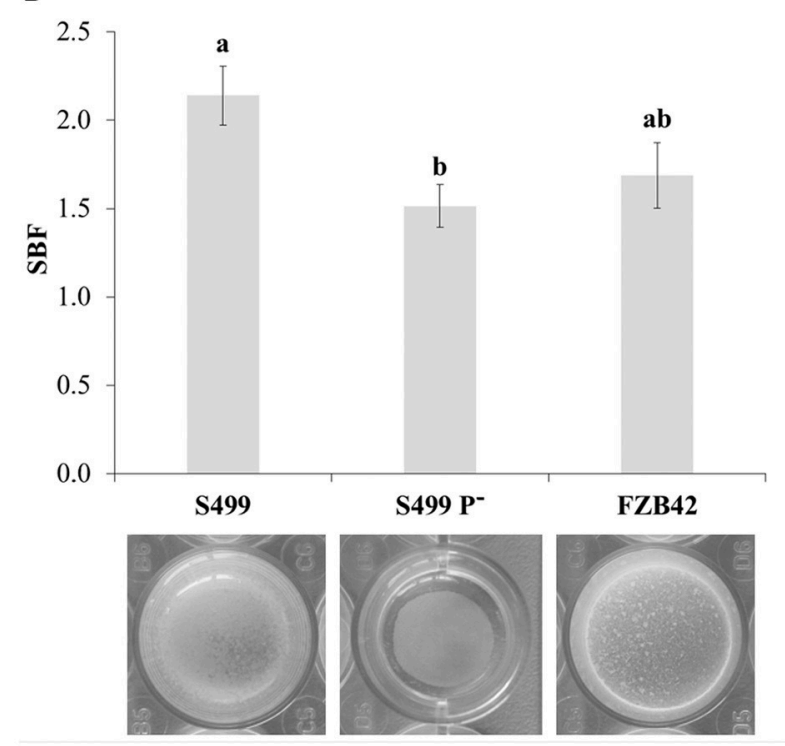

FIGURE 7 | Impact on swarming motility and biofilm formation. Values representing swarming motility on LBA (agar 0.5\%) (A) correspond to the averages of macrocolony diameters measured in dishes from one representative experiment (four replicates). Error bars represent standard errors. Different letters indicate significant differences according to Tukey's test $(\alpha=0.05)$. Specific biofilm formation (SBF) was measured after $72 \mathrm{~h}$ of incubation at $27^{\circ} \mathrm{C}$ in LB Broth (B). Values correspond to the averages of eight replicates in one representative experiment. Error bars represent standard errors. Different letters indicate significant differences according to Tukey's test $(\alpha=0.05)$.

$\pm 0.17)$ and FZB42 $(1.69 \pm 0.19) . S 499 \mathrm{P}^{-}$produced a pellicle at the liquid-air interface that was not attached to the edge of the wells, as it was for S499 and FZB42 (Figure 7B).

\section{Plasmid PS499 Influences Fengycin and Iturin-Dependent Antifungal Activity}

Since S499 produces fengycins and iturins, which show direct antifungal activity, we further investigated the effect of pS499 on fungal growth inhibition potential in vitro. Multifactorial ANOVA indicated a significant effect of the pathogen type $(p<$ $0.01)$, the Bacillus strain $(p<0.01)$ and the pathogen $\times$ Bacillus strain $(p<0.01)$ on the inhibition zones. The S499 $\mathrm{P}^{-}$strain was less effective than S499 and FZB42 in inhibiting the growth of C. cucumerinum and F. oxysporum f. sp. radicis-lycopersici, $\mathrm{S} 499$ and FZB42 were significantly more effective against $F$. oxysporum f. sp. radicis-lycopersici than against $C$. cucumerinum. Indeed, the inhibition zone was smaller for $\mathrm{S} 499 \mathrm{P}^{-}(1.6 \pm 0.2 \mathrm{~mm}$ against C. cucumerinum and $0.7 \pm 0.3 \mathrm{~mm}$ against $F$. oxysporum f. sp. radicis-lycopersici) compared to $\mathrm{S} 499(4.0 \pm 0.5 \mathrm{~mm} / 6.5 \pm 0.5$ $\mathrm{mm})$ and FZB42 $(4.5 \pm 0.2 \mathrm{~mm} / 7.0 \pm 0.4 \mathrm{~mm})$ (Figure 8A).

In these confrontation assays performed on gelified LB medium, bacterial cells evolve as microcolonies that can be viewed as a kind of biofilm-structured non-motile community. Their physiology may thus be quite different compared to the planktonic state, with a possible impact on CLP synthesis. Plugs of medium were removed from the inhibition zone to quantify the CLP pattern through UPLC-ESI-MS analysis. Regression analysis indicated a significant effect of iturin (positive, $p<0.01$, $\left.y=0.256 \mathrm{x}+2.522, R^{2}=0.245\right)$ and surfactin concentration (negative, $p<0.01, y=-0.618 \mathrm{x}+6.710, R^{2}=0.541$ ) on the size of inhibition zone, but not for fengycins.

Multifactorial ANOVA indicated a significant effect of the Bacillus strain $(p<0.01)$ on surfactin production, of the pathogen type $(p<0.01)$, the Bacillus strain $(p<0.01)$, and the pathogen $\times$ Bacillus strain $(p<0.01)$ on fengycin production, and of the Bacillus strain $(p<0.01)$ on iturin production. Surfactin production by S499 $\mathrm{P}^{-}\left(7.47 \pm 0.84 \mu \mathrm{g}\right.$ plug $^{-1}$ from the inhibition zone of C. cucumerinum and $7.69 \pm 0.75 \mu \mathrm{g} \mathrm{plug}^{-1}$ from the inhibition zone of $F$. oxysporum $\mathrm{f}$. sp. radicis-lycopersici) was significantly higher than by S499 $\left(3.36 \pm 0.63 \mu \mathrm{g} \mathrm{plug}^{-1}\right.$ and $3.94 \pm 1.05 \mu \mathrm{g} \mathrm{plug}^{-1}$ respectively) and FZB42 $(2.18 \pm 0.35$

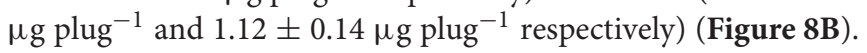
Fengycin production seemed to be stimulated by the presence of C. cucumerinum, but only in the case of FZB42. Indeed, in FZB42-C. cucumerinum dual cultures we detected $12.80 \pm 3.50$ $\mu \mathrm{g}$ plug $^{-1}$ of fengycins, whereas in FZB42-F. oxysporum f. sp. radicis-lycopersici dual cultures we detected $3.37 \pm 0.67 \mu \mathrm{g}$ plug $^{-1}$ of fengycins. The quantity of fengycins extracted from the inhibition zones around the colonies of S499 $\mathrm{P}^{-}$and S499 was similar and comprised between $1.03 \pm 0.23$ and $1.97 \pm$ $0.46 \mu \mathrm{g} \mathrm{plug}^{-1}$ (Figure 8C). Iturin production was lower in S499 $\mathrm{P}^{-}$compared to $\mathrm{S} 499$, in line with the trend observed in liquid cultures. Indeed, we detected only $2.93 \pm 0.84 \mu \mathrm{g} \mathrm{plug}^{-1}$ of iturins in $\mathrm{S} 499 \mathrm{P}^{-}-$C. cucumerinum dual cultures and $1.76 \pm$ $0.30 \mu \mathrm{g} \mathrm{plug}^{-1}$ in $\mathrm{S} 499 \mathrm{P}^{-}$-F. oxysporum $\mathrm{f}$. sp. radicis-lycopersici dual cultures, while we extracted $6.83 \pm 1.71 \mu \mathrm{g} \mathrm{plug}^{-1}$ and 8.85 $\pm 3.01 \mu \mathrm{g} \mathrm{plug}^{-1}$ from the respective inhibition zones of S499 (Figure 8D).

\section{DISCUSSION}

The efficacy of some B. amyloliquefaciens subsp. plantarum strains available on the market as biofungicides (Borriss, 2011) can be improved after elucidating the molecular mechanisms that govern the multiple interactions occurring among beneficial bacteria, pathogenic microorganisms, host plants and the environment (Raaijmakers et al., 2009; Dutta and Podile, 2010; Berendsen et al., 2012). Convinced that the availability of the 


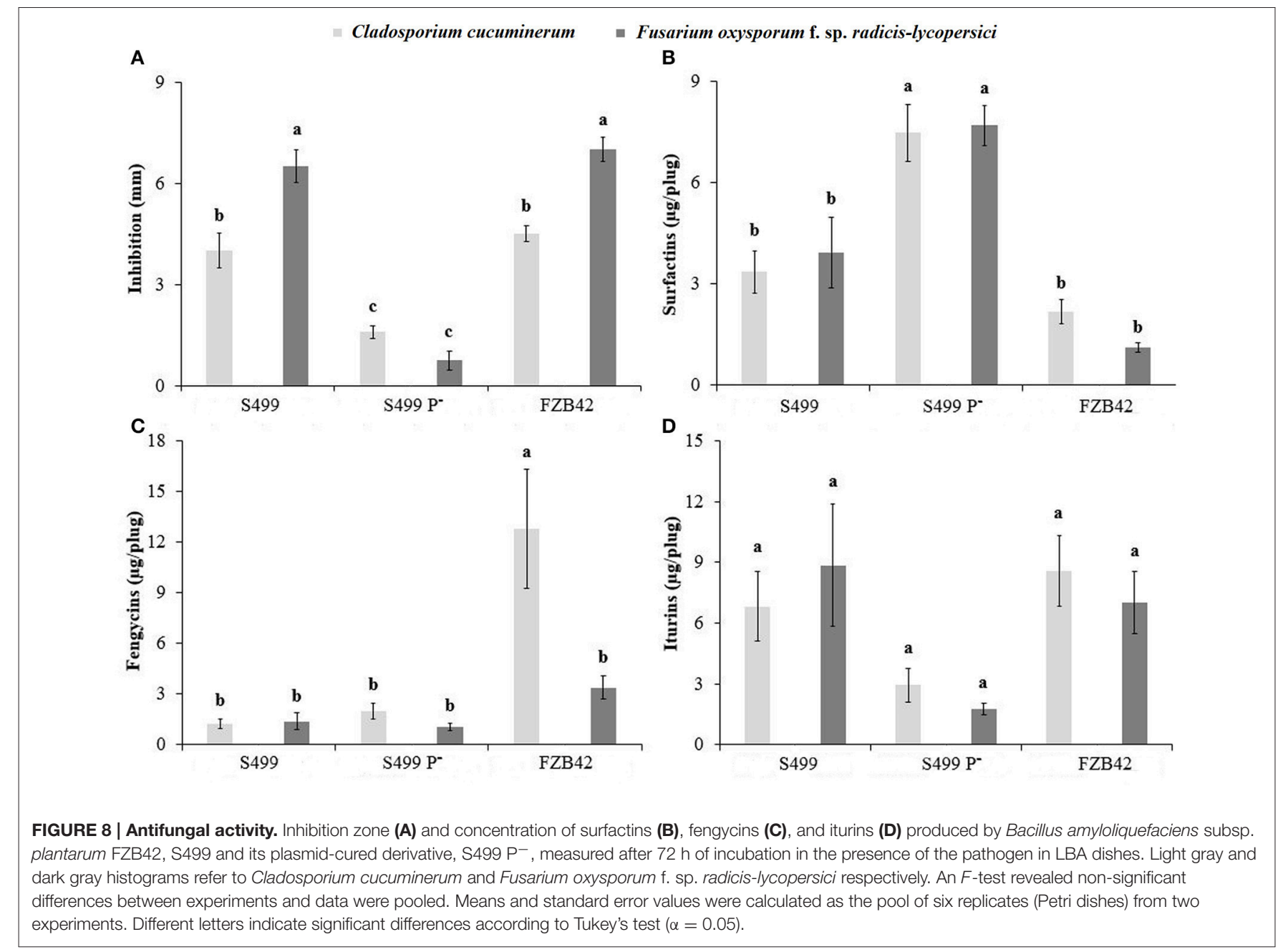

bacterial genomes may foster this elucidation, we compared the genomes of S499 and the well-characterized FZB42 (Chen et al., 2007) to find unique characteristics that may explain the S499 distinctive phenotype (Ongena et al., 2005b; Cawoy et al., 2014, 2015).

The genome comparison showed a high degree of genetic conservation between the two strains. A large percentage of sequence identity was found for the genes responsible for root colonization, plant growth promotion, and biocontrol. Therefore, we hypothesize that divergences in regulatory elements could explain the different behavior of the bacteria, especially influencing their sensing of and adaptation to the environment. Indeed, some specific genes were identified as transcriptional factors or annotated as hypothetical proteins and it would be challenging to analyse how they contribute to determining the phenotypic differences observed between S499 and FZB42. Some other unique CDS encode transport proteins, such as $\mathrm{ABC}$ transporter permeases (e.g., AS588_RS00475, AS588_RS09125, RBAM_RS18310) and other transmembrane proteins (e.g., RBAM_RS01165, RBAM_RS02920), that might play a role in perceiving and responding to the environment in different ways for S499 and FZB42. In general, cell membrane transport systems are crucial for the survival of many microorganisms in natural conditions (Konings, 2006). For example, surface colonization relies on the efficient transfer of potassium ions $\left(\mathrm{K}^{+}\right)$in $B$. subtilis, since a mutation in the $\mathrm{K}^{+}$ transporter KtrAB prevents cell spreading (Kinsinger et al., 2005).

Within unique CDS in the S499 genome, phage-related sequences were also more numerous. Phages represent one of the main channels in horizontal gene transfer, therefore genetic variability among bacterial strains is significantly dependant on prophage acquisition (Brüssow and Hendrix, 2002). According to Wang et al. (2010), cryptic prophages help the host to overcome adverse environmental conditions (oxidative, osmotic, and acid stress). An abundance of prophage regions could reflect a higher plasticity of the $\$ 499$ genome. This hypothesis is also supported by the presence of genomic rearrangements and plasmid DNA, which are other features contributing to genetic variation in bacteria and their rapid evolution (Van Elsas et al., 2000; Dobrindt and Hacker, 2001). 
The presence of a plasmid (pS499) emerged as a distinctive feature of S499, as shown by our comparative analysis. This is an interesting aspect, given the fact that plasmids are not frequent either in the available sequenced strains or in other Bacillus spp. strains (23, 76, 98R, 98S, 104, GA1) also identified as good antibiotic producers in our laboratory (Cawoy et al., 2015). Based on its size and structural organization, pS499 can be ascribed to the class of small rolling circle replicons (Guglielmetti et al., 2007). These natural plasmids have a typical organization that includes a replication module, a gene responsible for plasmid mobilization and one or more modules not involved in plasmid metabolism but encoding traits related to the host physiology. For instance, in some strains the plasmid encodes a heat shock protein putatively involved in stress responses, which may represent an advantage for the bacterium in its natural environment (Thorsted et al., 1999). Some impact of pS499 on the physiology of S499 can be expected from the presence of a rap-phr cassette. Indeed, some plasmid-encoded response regulator aspartate phosphatases have already been proven to control extracellular protease production, biofilm architecture, sporulation, and the genetic competence of B. subtilis and $B$. amyloliquefaciens (Meijer et al., 1998; Koetje et al., 2003; Parashar et al., 2013; Boguslawski et al., 2015). As the rap gene located on pS499 was expressed in S499 cells from an early growth phase, a role in regulating the cellular physiology of the bacterium can be foreseen.

Chromosome-encoded Rap-Phr systems have been extensively studied in B. subtilis, where they control cellular processes regulated by two-component systems, such as competence development, antibiotic synthesis, protein secretion, and sporulation (Perego et al., 1994; Bongiorni et al., 2005; Auchtung et al., 2006). Rap proteins (11 members in $B$. subtilis) counteract kinases by dephosphorylating intracellular response regulators (e.g., Spo0F) or alternatively, they inhibit transcriptional factors such as ComA and DegU in their DNA binding activity (Bongiorni et al., 2005). Seven of the 11 characterized rap genes are followed by a phr gene, encoding a phosphatase regulator (Phr) precursor peptide. Phr peptides are extracellularly processed to pentapeptides. Once they reach a critical concentration, therefore acting as quorum sensing signals, the mature peptides are reimported through an oligopeptide permease (Opp) into the cytoplasm, where they inhibit Rap proteins (Pottathil and Lazazzera, 2003). Besides the rap-phr cassette located on pS499, we also identified 10 rap genes in the S499 chromosome, with rapI_1 representing another difference between S499 and FZB42. Having rapI_1 and an additional rap-phr cassette encoded by a plasmid, which can further increase its copy number, could constitute an ecological advantage for S499 compared to FZB42. Interestingly, Thorsted et al. (1999) highlighted that the presence of plasmid-encoded rap genes is more diffuse among Russian strains isolated from the soil rather than in strains selected to be used in the Japanese fermentation industry. By curing S499 of its plasmid, we aimed to elucidate the role played by the Rap-Phr system encoded by pS499 in the phenotypic differences that have so far been characterized in S499 and FZB42.
The absence of the rap-phr cassette located on pS499 caused faster growth of $\mathrm{S} 499 \mathrm{P}^{-}$compared to the wild strain, which could be linked to improved substrate utilization ability by the cured cells. Indeed, increased activity of secreted proteases was observed for $\mathrm{S} 499 \mathrm{P}^{-}$. The increase in proteolytic activity is in accordance with previous studies showing that the pTA1060-encoded Rap60-Phr60 system controls the secretion of proteolytic enzymes. More precisely, rap60 is involved in down-regulation of the aprE gene (responsible for production of the extracellular protease subtilisin) during post-exponential growth (Koetje et al., 2003; Boguslawski et al., 2015) through a complex molecular pathway. The rap gene of pS499 displays 71\% sequence identity with rap60 at nucleotide level. Nevertheless, in our case, increased proteolytic activity of S499 $\mathrm{P}^{-}$was also observed during the early growth phase $(6 \mathrm{~h})$, with very low biomass. Thus, it is conceivable that the rap-phr cassette of pS499 may behave differently from pTA1060-encoded Rap60Phr60, although the same negative control on the secretion of extracellular proteases can be assumed. Consistently with the earlier start of exponential growth phase for FZB42, both azocasein and skimmed milk assays showed that FZB42 extracellular proteolytic activity was higher compared to S499 $\mathrm{P}^{-}$. Therefore, in addition to the plasmid, other genetic features are responsible for the different phenotypes of FZB42 and S499.

The higher growth rate of $\mathrm{S} 499 \mathrm{P}^{-}$can only partially be explained by the increased production of proteases. Indeed, in modified LB cultures the S499 curve did not overlap that of $\mathrm{S} 499 \mathrm{P}^{-}$, but still rose later and showed a milder slope. Another possible explanation for the observed growth shift is related to the energy cost of pS499 replication in S499 cells. Indeed, the presence of plasmids is frequently associated with reduced growth rates, especially in the case of large and high copy number plasmids (Smith and Bidochka, 1998; Diaz Ricci and Hernández, 2000). For example, Trautwein et al. (2016) recently reported that deletion of the $262 \mathrm{~Kb}$ native plasmid in Phaeobacter inhibens DSM 17395 improved the growth efficiency of the strain. They hypothesized that either the plasmid delays cell division by slowing down the DNA replication process, or that it has a metabolic weight that compromises growth efficiency. Even if pS499 is considerably reduced in size, we can assume a similar fitness cost for the host cells. However, it is worth noting that S499 tended to keep its plasmid during cell multiplication, despite the hypothesized energy cost. In fact, although exposed to sublethal conditions during our curing procedure, plasmid loss was a rare event in S499. This corroborates the hypothesis that pS499 could provide a real selective advantage in natural environments, as in the case of pQBR103 from Pseudomonas fluorescens for example (Lilley and Bailey, 1997) and many other bacterial plasmids (Thomas, 2004).

Plasmid curing considerably affected the CLP production by $\mathrm{S} 499$. Kinetic assay showed that $\mathrm{S} 499 \mathrm{P}^{-}$behaves similarly to FZB42 as far as surfactin is concerned, suggesting a role of the plasmid in regulating surfactin synthesis. However, it remains unclear whether earlier production by $\mathrm{S} 499 \mathrm{P}^{-}$is due to earlier entrance in the exponential phase or to divergences 
in transcriptional regulation. Indeed, it is known that srfA gene expression is cell-density dependent, being controlled by the ComP-ComA signal transduction system (Nakano et al., 1991). Given the differences observed in growth rates, earlier surfactin production could be related to faster multiplication of S499 $\mathrm{P}^{-}$and FZB42 populations. Nevertheless, we noted that the cured strain accumulated many more surfactins than FZB42 and S499 over time. Consistently, srfA gene expression was downregulated in B. subtilis OKB105 transformed with the plasmidencoded rap gene from B. amyloliquefaciens subsp. plantarum NAU-B3 (99\% nucleotide sequence identity with pS499 rap; Yang et al., 2015). Furthermore, it has been demonstrated that the Rap phosphatase modulates srfA transcription by forming a ternary complex with ComA and srfA promoter (Yang et al., 2015). Similarly, we can postulate that loss of the pS499 rap gene enhanced srfA expression because of the removal of inhibition in the cured strain. Conversely, no significant differences between the cured strain and its parental strain were observed in terms of the release of fengycins and iturins. We can therefore assume that the differences between S499 and FZB42 observed in the production of these CLPs mostly depend on a different regulatory pathway, not involving pS499.

As a consequence of different surfactin production, in $\mathrm{S} 499 \mathrm{P}^{-}$ some phenotypic traits related to rhizosphere competence were affected, e.g., the speed of surface colonization. Bacillus spp. are capable of multicellular behavior known as swarming motility, a common bacterial way of moving across surfaces powered by rotating flagella (Kearns and Losick, 2003). Swarming motility is highly dependent on the secretion of surfactins, which reduce surface tension given their amphiphilic nature (Kinsinger et al., 2003; Leclère et al., 2006; Kearns, 2010). Therefore, a boost in surfactin production by $\mathrm{S} 499 \mathrm{P}^{-}$can explain the increase in its swarming ability. Similarly, the faster surface spreading of FZB42 can be related to higher production of surfactins compared to $\mathrm{S} 499$, but not to $\mathrm{S} 499 \mathrm{P}^{-}$. Indeed, according to our kinetic assays, the surfactin production rates of $\mathrm{S} 499 \mathrm{P}^{-}$and FZB42 were similar. Here we can speculate that the phenotypes were influenced by the different growth rates of the strains. Even without reaching a final conclusion on the mechanism involved, we can assume that the presence of the plasmid could be necessary in the process of root surface colonization by $\$ 499$, because swarming motility is a major factor favoring root colonization, even more than chemotaxis (Gao et al., 2016).

Bacillus spp. develop in the rhizosphere in the form of biofilms, which are also crucial for the biocontrol of plant pathogens (Bais et al., 2004; Chen et al., 2012, 2013). SBF values were lower for FZB42 compared to S499 and on curing S499 we observed a further reduction in SBF in S499 $\mathrm{P}^{-}$. These results suggest a role for the plasmid in determining the difference found between S499 and FZB42. Surfactins function as paracrine signals that induce the differentiation of biofilm matrix producer cells (López et al., 2009). By regulating the phosphorylation state of DegU, ComA, and Spo0A, different Rap phosphatases control multiple signaling cascades. This redundant network can integrate exogenous and endogenous signals, leading to the formation of distinct biofilm subpopulations (motile cells, matrix producers, competent cells, cannibals, etc.; Mielich-Süss and Lopez, 2015). In the light of the increased and earlier surfactin production associated with plasmid curing, we would have expected an increase rather than a reduction in SBF. However, it is likely that very small amounts of this lipopeptide are sufficient to trigger biofilm formation and that other factors become more important later. It has indeed been observed that the surfactinproducing subpopulation is actually restrained in biofilm layers (Mielich-Süss and Lopez, 2015). Although considerable effort is required to understand which specific pathway is targeted by the pS499-encoded Rap, we can assume that its lack is most probably the cause of the altered phenotype observed for $\$ 499$ $\mathrm{P}^{-}$. Likewise, McLoon et al. (2011) showed that RapP encoded by an $80 \mathrm{~Kb}$ plasmid from B. subtilis NCIB 3610 is required for the formation of robust biofilms typical of wild-type strains. Later studies revealed that RapP is a Spo0F phosphatase and that it is involved in the phosphorelay modulating the expression of epsA-O and yqxM-sipW-tasA biofilm operons (Parashar et al., 2013).

Similarly to previous results (Cawoy et al., 2015), regression analysis of the antagonism assay showed that limited iturin production affected the intrinsic ability of $\mathrm{S} 499 \mathrm{P}^{-}$to inhibit the mycelial growth of C. cucumerinum and F. oxysporum f. sp. lycopersici. Furthermore, it is conceivable that the negative correlation with surfactin concentration resulted from a physiological imbalance: the more resources were allocated to the synthesis of surfactins, in particular by $S 499 \mathrm{P}^{-}$, the fewer were available for synthesis of iturins, which are known to be produced in the stationary phase of bacterial growth (Jacques et al., 1999). Plasmid pS499 is therefore indirectly relevant for the antifungal activity of the strain, being involved in the modulation of lipopeptide production. At all events, the fact that S499 and FZB42 produced similar quantities of iturins in dual culture with the pathogens suggests that other genetic traits are also involved.

In conclusion, our data show that the plasmid-encoded rap gene of B. amyloliquefaciens subsp. plantarum S499 has a role in controlling several traits like protease secretion, production of surfactins and biofilm formation. Growth and motility are also influenced, either indirectly by the pS499 Rap-Phr system and/or by the presence of the plasmid itself. To our knowledge, we provide here the first report on the relationship between a plasmid, or control of Rap phosphatase on fengycin and iturin production, and the related impact on biocontrol. To illustrate these molecular pathways more exhaustively, further studies on the cellular mechanisms are necessary. Finally, by comparing the behavior of FZB42 and the S499 plasmid-cured derivative S499 $\mathrm{P}^{-}$, we can conclude that $\mathrm{pS} 499$ plays a significant role in the phenotype of the two strains, although other genetic differences merit additional investigation.

\section{AUTHOR CONTRIBUTIONS}

GM carried out all the experiments, analyzed the data and wrote and edited the manuscript. LF carried out UPLC-ESI-MS analysis and wrote and edited the manuscript. SS carried out 
qRT-PCR and wrote and edited the manuscript. GP, IP, and MO conceived the work, designed the experiments, analyzed the data and wrote and edited the manuscript. All the authors have read the manuscript and agreed to its content.

\section{ACKNOWLEDGMENTS}

This research was supported by the EU project INNOVA (subprogram: FP7-PEOPLE-2012-IAPP, grant agreement:

\section{REFERENCES}

Ågren, J., Sundström, A., Håfström, T., and Segerman, B. (2012). Gegenees: fragmented alignment of multiple genomes for determining phylogenomic distances and genetic signatures unique for specified target groups. PLOS ONE 7:e39107. doi: 10.1371/journal.pone.0039107

Alikhan, N. F., Petty, N. K., Zakour, N. L. B., and Beatson, S. A. (2011). BLAST Ring Image Generator (BRIG): simple prokaryote genome comparisons. BMC Genomics 12:402. doi: 10.1186/1471-2164-12-402

Auchtung, J. M., Lee, C. A., and Grossman, A. D. (2006). Modulation of the ComAdependent quorum response in Bacillus subtilis by multiple rap proteins and Phr peptides. J. Bacteriol. 188, 5273-5285. doi: 10.1128/JB.00300-06

Bais, H. P., Fall, R., and Vivanco, J. M. (2004). Biocontrol of Bacillus subtilis against infection of Arabidopsis roots by Pseudomonas syringae is facilitated by biofilm formation and surfactin production. Plant Physiol. 134, 307-319. doi: $10.1104 /$ pp.103.028712

Bakker, P. A., Doornbos, R. F., Zamioudis, C., Berendsen, R. L., and Pieterse, C. M. (2013). Induced systemic resistance and the rhizosphere microbiome. Plant Pathol. J. 29, 136-143. doi: 10.5423/PPJ.SI.07.2012.0111

Berendsen, R. L., Pieterse, C. M., and Bakker, P. A. (2012). The rhizosphere microbiome and plant health. Trends Plant Sci. 17, 478-486. doi: 10.1016/j.tplants.2012.04.001

Boguslawski, K. M., Hill, P. A., and Griffith, K. L. (2015). Novel mechanisms of controlling the activities of the transcription factors Spo0A and ComA by the plasmid-encoded quorum sensing regulators Rap60-Phr60 in Bacillus subtilis. Mol. Microbiol. 96, 325-348. doi: 10.1111/mmi.12939

Bongiorni, C., Ishikawa, S., Stephenson, S., Ogasawara, N., and Perego, M. (2005). Synergistic regulation of competence development in Bacillus subtilis by two Rap-Phr systems. J. Bacteriol. 187, 4353-4361. doi: 10.1128/JB.187.13.4353-4361.2005

Borriss, R. (2011). "Use of plant-associated Bacillus strains as biofertilizers and biocontrol agents," in Bacteria in Agrobiology: Plant Growth Responses, ed D. K. Maheshwari (Berlin; Heidelberg: Springer-Verlag), 41-76. doi: 10.1007/978-3-642-20332-9_3

Borriss, R., Chen, X. H., Rueckert, C., Blom, J., Becker, A., Baumgarth, B., et al. (2011). Relationship of Bacillus amyloliquefaciens clades associated with strains DSM 7T and FZB42T: a proposal for Bacillus amyloliquefaciens subsp. amyloliquefaciens subsp. nov. and Bacillus amyloliquefaciens subsp. plantarum subsp. nov. based on complete genome sequence comparisons. Int. J. Syst. Evol. Microbiol. 61, 1786-1801. doi: 10.1099/ijs.0.023267-0

Brüssow, H., and Hendrix, R. W. (2002). Phage genomics: small is beautiful. Cell 108, 13-16. doi: 10.1016/S0092-8674(01)00637-7

Cawoy, H., Bettiol, W., Fickers, P., and Ongena, M. (2011). "Bacillusbased biological control of plant diseases," in Pesticides in the Modern World-Pesticides Use and Management, ed M. Stoytcheva (Rijeka: InTech), 273-302.

Cawoy, H., Debois, D., Franzil, L., De Pauw, E., Thonart, P., and Ongena, M. (2015). Lipopeptides as main ingredients for inhibition of fungal phytopathogens by Bacillus subtilis/amyloliquefaciens. Microb. Biotechnol. 8, 281-295. doi: 10.1111/1751-7915.12238

Cawoy, H., Mariutto, M., Henry, G., Fisher, C., Vasilyeva, N., Thonart, P., et al. (2014). Plant defense stimulation by natural isolates of Bacillus depends on efficient surfactin production. Mol. Plant Microbe Interact. 27, 87-100. doi: 10.1094/MPMI-09-13-0262-R
324416). M. Ongena is Senior Research Associate at the F.R.S.-FNRS (Fonds National de la Recherche Scientifique) in Belgium.

\section{SUPPLEMENTARY MATERIAL}

The Supplementary Material for this article can be found online at: http://journal.frontiersin.org/article/10.3389/fmicb. 2017.00017/full\#supplementary-material
Chen, X. H., Koumoutsi, A., Scholz, R., Eisenreich, A., Schneider, K., Heinemeyer, I., et al. (2007). Comparative analysis of the complete genome sequence of the plant growth-promoting bacterium Bacillus amyloliquefaciens FZB42. Nat. Biotechnol. 25, 1007-1014. doi: 10.1038/nbt1325

Chen, X. H., Koumoutsi, A., Scholz, R., Schneider, K., Vater, J., Süssmuth, R., et al. (2009). Genome analysis of Bacillus amyloliquefaciens FZB42 reveals its potential for biocontrol of plant pathogens. J. Biotechnol. 140, 27-37. doi: 10.1016/j.jbiotec.2008.10.011

Chen, Y., Cao, S., Chai, Y., Clardy, J., Kolter, R., Guo, J. H., et al. (2012). A Bacillus subtilis sensor kinase involved in triggering biofilm formation on the roots of tomato plants. Mol. Microbiol. 85, 418-430. doi: 10.1111/j.1365-2958.2012.08109.x

Chen, Y., Yan, F., Chai, Y., Liu, H., Kolter, R., Losick, R., et al. (2013). Biocontrol of tomato wilt disease by Bacillus subtilis isolates from natural environments depends on conserved genes mediating biofilm formation. Environ. Microbiol. 15, 848-864. doi: 10.1111/j.1462-2920.2012.02860.x

Chowdhury, S. P., Hartmann, A., Gao, X., and Borriss, R. (2015). Biocontrol mechanism by root-associated Bacillus amyloliquefaciens FZB42-a review. Front. Microbiol. 6:780. doi: 10.3389/fmicb.2015.00780

Darling, A. E., Mau, B., and Perna, N. T. (2010). ProgressiveMauve: multiple genome alignment with gene gain, loss and rearrangement. PLoS ONE 5:e11147. doi: 10.1371/journal.pone.0011147

Debois, D., Fernandez, O., Franzil, L., Jourdan, E., Brogniez, A., Willems, L., et al. (2015). Plant polysaccharides initiate underground crosstalk with bacilli by inducing synthesis of the immunogenic lipopeptide surfactin. Environ. Microbiol. Rep. 7, 570-582. doi: 10.1111/1758-2229.12286

Diaz Ricci, J. C., and Hernández, M. E. (2000). Plasmid effects on Escherichia coli metabolism. Crit. Rev. Biotechnol. 20, 79-108. doi: 10.1080/07388550008984167

Dobrindt, U., and Hacker, J. (2001). Whole genome plasticity in pathogenic bacteria. Curr. Opin. Microbiol. 4, 550-557. doi: 10.1016/S1369-5274(00)00250-2

Dunlap, C. A., Kim, S. J., Kwon, S. W., and Rooney, A. P. (2015). Phylogenomic analysis shows that Bacillus amyloliquefaciens subsp. plantarum is a later heterotypic synonym of Bacillus methylotrophicus. Int. J. Syst. Evol. Microbiol. 65, 2104-2109. doi: 10.1099/ijs.0.000226

Dunlap, C. A., Kim, S. J., Kwon, S. W., and Rooney, A. P. (2016). Bacillus velezensis is not a later heterotypic synonym of Bacillus amyloliquefaciens; Bacillus methylotrophicus, Bacillus amyloliquefaciens subsp. plantarum and 'Bacillus oryzicola' are later heterotypic synonyms of Bacillus velezensis based on phylogenomics. Int. J. Syst. Evol. Microbiol. 66, 1212-1217. doi: 10.1099/ijsem.0.000858

Dutta, S., and Podile, A. R. (2010). Plant growth promoting rhizobacteria (PGPR): the bugs to debug the root zone. Crit. Rev. Microbiol. 36, 232-244. doi: 10.3109/10408411003766806

Felsenstein, J. (1989). PHYLIP (Version 3.6) Phylogeny Inference Package. Cladistics 5, 164-166.

Feng, J., Gu, Y., Wang, J., Song, C., Yang, C., Xie, H., et al. (2013). Curing the plasmid pMC1 from the poly $(\gamma$-glutamic acid) producing Bacillus amyloliquefaciens LL3 strain using plasmid incompatibility. Appl. Biochem. Biotechnol. 171, 532-542. doi: 10.1007/s12010-013-0382-0

Gao, S., Wu, H., Yu, X., Qian, L., and Gao, X. (2016). Swarming motility plays the major role in migration during tomato root colonization by Bacillus subtilis SWR01. Biol. Control 98, 11-17. doi: 10.1016/j.biocontrol.2016.03.011 
Guglielmetti, S., Mora, D., and Parini, C. (2007). Small rolling circle plasmids in Bacillus subtilis and related species: organization, distribution, and their possible role in host physiology. Plasmid 57, 245-264. doi: 10.1016/j.plasmid.2006.09.002

Jacques, P., Hbid, C., Destain, J., Razafindralambo, H., Paquot, M., De Pauw, E., et al. (1999). Optimization of biosurfactant lipopeptide production from Bacillus subtilis $\$ 499$ by Plackett-Burman design. Appl. Biochem. Biotechnol. 77, 223-233. doi: 10.1385/ABAB:77:1-3:223

Julkowska, D., Obuchowski, M., Holland, I. B., and Séror, S. J. (2005). Comparative analysis of the development of swarming communities of Bacillus subtilis 168 and a natural wild type: critical effects of surfactin and the composition of the medium. J. Bacteriol. 187, 65-76. doi: 10.1128/JB.187.1.65-76.2005

Kearns, D. B. (2010). A field guide to bacterial swarming motility. Nat. Rev. Microbiol. 8, 634-644. doi: 10.1038/nrmicro2405

Kearns, D. B., and Losick, R. (2003). Swarming motility in undomesticated Bacillus subtilis. Mol. Microbiol. 49, 581-590. doi: 10.1046/j.1365-2958.2003.03584.x

Kim, P. I., Ryu, J., Kim, Y. H., and Chi, Y. T. (2010). Production of biosurfactant lipopeptides Iturin A, fengycin and surfactin A from Bacillus subtilis CMB32 for control of Colletotrichum gloeosporioides. J. Microbiol. Biotechnol. 20, 138-145. doi: $10.4014 / j \mathrm{mb} .0905 .05007$

Kinsinger, R. F., Kearns, D. B., Hale, M., and Fall, R. (2005). Genetic requirements for potassium ion-dependent colony spreading in Bacillus subtilis. J. Bacteriol. 187, 8462-8469. doi: 10.1128/JB.187.24.8462-8469.2005

Kinsinger, R. F., Shirk, M. C., and Fall, R. (2003). Rapid surface motility in Bacillus subtilis is dependent on extracellular surfactin and potassium ion. J. Bacteriol. 185, 5627-5631. doi: 10.1128/JB.185.18.5627-5631.2003

Koetje, E. J., Hajdo-Milasinovic, A., Kiewiet, R., Bron, S., and Tjalsma, H. (2003). A plasmid-borne Rap-Phr system of Bacillus subtilis can mediate cell-density controlled production of extracellular proteases. Microbiology 149, 19-28. doi: $10.1099 /$ mic. $0.25737-0$

Konings, W. N. (2006). Microbial transport: adaptations to natural environments. Anton. Van Leeuwenhoek 90, 325-342. doi: 10.1007/s10482-006-9089-3

Koumoutsi, A., Chen, X. H., Henne, A., Liesegang, H., Hitzeroth, G., Franke, P., et al. (2004). Structural and functional characterization of gene clusters directing nonribosomal synthesis of bioactive cyclic lipopeptides in Bacillus amyloliquefaciens strain FZB42. J. Bacteriol. 186, 1084-1096. doi: 10.1128/JB.186.4.1084-1096.2004

Kumar, A., Prakash, A., and Johri, B. N. (2011). "Bacillus as PGPR in crop ecosystem," in Bacteria in Agrobiology: Crop Ecosystems, ed D. K. Maheshwari (Berlin; Heidelberg: Springer-Verlag), 37-59. doi: 10.1007/978-3-642-18357-7_2

Leclère, V., Marti, R., Béchet, M., Fickers, P., and Jacques, P. (2006). The lipopeptides mycosubtilin and surfactin enhance spreading of Bacillus subtilis strains by their surface-active properties. Arch. Microbiol. 186, 475-483. doi: $10.1007 / \mathrm{s} 00203-006-0163-\mathrm{z}$

Lilley, A. K., and Bailey, M. J. (1997). Impact of plasmid pQBR103 acquisition and carriage on the phytosphere fitness of Pseudomonas fluorescens SBW25: burden and benefit. Appl. Environ. Microbiol. 63, 1584-1587.

Livak, K. J., and Schmittgen, T. D. (2001). Analysis of relative gene expression data using real-time quantitative PCR and the $2^{-\Delta \Delta \mathrm{CT}}$ method. Methods 25, 402-408. doi: 10.1006/meth.2001.1262

López, D., Vlamakis, H., Losick, R., and Kolter, R. (2009). Paracrine signaling in a bacterium. Gene. Dev. 23, 1631-1638. doi: 10.1101/gad.1813709

Lugtenberg, B., and Kamilova, F. (2009). Plant-growthpromoting rhizobacteria. Annu. Rev. Microbiol. 63, 541-556. doi: 10.1146/annurev.micro.62.081307.162918

Maget-Dana, R., and Peypoux, F. (1994). Iturins, a special class of poreforming lipopeptides: biological and physicochemical properties. Toxicology 87, 151-174. doi: 10.1016/0300-483X(94)90159-7

McLoon, A. L., Guttenplan, S. B., Kearns, D. B., Kolter, R., and Losick, R. (2011). Tracing the domestication of a biofilm-forming bacterium. J. Bacteriol. 193, 2027-2034. doi: 10.1128/JB.01542-10

Meijer, W. J., Wisman, G. B. A., Terpstra, P., Thorsted, P. B., Thomas, C. M., Holsappel, S., et al. (1998). Rolling-circle plasmids from Bacillus subtilis: complete nucleotide sequences and analyses of genes of pTA1015, pTA1040, pTA1050 and pTA1060, and comparisons with related plasmids from gram-positive bacteria. FEMS Microbiol. Rev. 21, 337-368. doi: 10.1111/j.1574-6976.1998.tb00357.x
Mielich-Süss, B., and Lopez, D. (2015). Molecular mechanisms involved in Bacillus subtilis biofilm formation. Environ. Microbiol. 17, 555-565. doi: 10.1111/1462-2920.12527

Molinatto, G., Puopolo, G., Sonego, P., Moretto, M., Engelen, K., Viti, C., et al. (2016). Complete genome sequence of Bacillus amyloliquefaciens subsp. plantarum S499, a rhizobacterium that triggers plant defences and inhibits fungal phytopathogens. J. Biotechnol. 238, 56-59. doi: 10.1016/j.jbiotec.2016.09.013

Nakano, M. M., Xia, L. A., and Zuber, P. (1991). Transcription initiation region of the srfA operon, which is controlled by the comP-comA signal transduction system in Bacillus subtilis. J. Bacteriol. 173, 5487-5493. doi: 10.1128/jb.173.17.5487-5493.1991

Nihorimbere, V., Cawoy, H., Seyer, A., Brunelle, A., Thonart, P., and Ongena, M. (2012). Impact of rhizosphere factors on cyclic lipopeptide signature from the plant beneficial strain Bacillus amyloliquefaciens S499. FEMS Microbiol. Ecol. 79, 176-191.doi: 10.1111/j.1574-6941.2011.01208.x

Nihorimbere, V., Ongena, M., Smargiassi, M., and Thonart, P. (2011). Beneficial effect of the rhizosphere microbial community for plant growth and health. Biotechnol. Agron. Soc. 15, 327-337.

Ongena, M., Duby, F., Jourdan, E., Beaudry, T., Jadin, V., Dommes, J., et al. (2005b). Bacillus subtilis M4 decreases plant susceptibility towards fungal pathogens by increasing host resistance associated with differential gene expression. Appl. Microbiol. Biotechnol. 67, 692-698. doi: 10.1007/s00253-004-1741-0

Ongena, M., and Jacques, P. (2008). Bacillus lipopeptides: versatile weapons for plant disease biocontrol. Trends Microbiol. 16, 115-125. doi: 10.1016/j.tim.2007.12.009

Ongena, M., Jacques, P., Touré, Y., Destain, J., Jabrane, A., and Thonart, P. (2005a). Involvement of fengycin-type lipopeptides in the multifaceted biocontrol potential of Bacillus subtilis. Appl. Microbiol. Biotechnol. 69, 29-38. doi: 10.1007/s00253-005-1940-3

Ongena, M., Jourdan, E., Adam, A., Paquot, M., Brans, A., Joris, B., et al. (2007). Surfactin and fengycin lipopeptides of Bacillus subtilis as elicitors of induced systemic resistance in plants. Environ. Microbiol. 9, 1084-1090. doi: 10.1111/j.1462-2920.2006.01202.x

Overbeek, R., Begley, T., Butler, R. M., Choudhuri, J. V., Chuang, H. Y., Cohoon, M., et al. (2005). The subsystems approach to genome annotation and its use in the project to annotate 1000 genomes. Nucl. acids Res. 33, 5691-5702. doi: 10.1093/nar/gki866

Parashar, V., Konkol, M. A., Kearns, D. B., and Neiditch, M. B. (2013). A plasmid-encoded phosphatase regulates Bacillus subtilis biofilm architecture, sporulation, and genetic competence. J. Bacteriol. 195, 2437-2448. doi: 10.1128/JB.02030-12

Perego, M., Hanstein, C., Welsh, K. M., Djavakhishvili, T., Glaser, P., and Hoch, J. A. (1994). Multiple protein-aspartate phosphatases provide a mechanism for the integration of diverse signals in the control of development in B. subtilis. Cell 79, 1047-1055. doi: 10.1016/0092-8674(94)90035-3

Pertot, I., Puopolo, G., Hosni, T., Pedrotti, L., Jourdan, E., and Ongena, M. (2013). Limited impact of abiotic stress on surfactin production in planta and on disease resistance induced by Bacillus amyloliquefaciens S499 in tomato and bean. FEMS Microbiol. Ecol. 86, 505-519. doi: 10.1111/1574-6941. 12177

Peypoux, F., Bonmatin, J. M., and Wallach, J. (1999). Recent trends in the biochemistry of surfactin. Appl. Microbiol. Biotechnol. 51, 553-563. doi: $10.1007 / \mathrm{s} 002530051432$

Pottathil, M., and Lazazzera, B. A. (2003). The extracellular Phr peptide-Rap phosphatase signaling circuit of Bacillus subtilis. Front. Biosci. 8:d32-45. doi: $10.2741 / 913$

Raaijmakers, J. M., De Bruijn, I., Nybroe, O., and Ongena, M. (2010). Natural functions of lipopeptides from Bacillus and Pseudomonas: more than surfactants and antibiotics. FEMS Microbiol. Rev. 34, 1037-1062. doi: 10.1111/j.1574-6976.2010.00221.x

Raaijmakers, J. M., Paulitz, T. C., Steinberg, C., Alabouvette, C., and MoënneLoccoz, Y. (2009). The rhizosphere: a playground and battlefield for soilborne pathogens and beneficial microorganisms. Plant Soil 321, 341-361. doi: 10.1007/s11104-008-9568-6

Ramarathnam, R., Bo, S., Chen, Y., Fernando, W. D., Xuewen, G., and De Kievit, T. (2007). Molecular and biochemical detection of fengycin-and bacillomycin 
D-producing Bacillus spp., antagonistic to fungal pathogens of canola and wheat. Can. J. Microbiol. 53, 901-911. doi: 10.1139/W07-049

Romero, D., de Vicente, A., Rakotoaly, R. H., Dufour, S. E., Veening, J. W., Arrebola, E., et al. (2007). The iturin and fengycin families of lipopeptides are key factors in antagonism of Bacillus subtilis toward Podosphaera fusca. Mol. Plant. Microbe. Interact. 20, 430-440. doi: 10.1094/MPMI-20-4-0430

Seemann, T. (2014). Prokka: rapid prokaryotic genome annotation. Bioinformatics 30, 2068-2069. doi: 10.1093/bioinformatics/btu153

Smith, M. A., and Bidochka, M. J. (1998). Bacterial fitness and plasmid loss: the importance of culture conditions and plasmid size. Can. J. Microbiol. 44, 351-355. doi: 10.1139/w98-020

Thomas, C. M. (2004). "Evolution and population genetics of bacterial plasmids," in Plasmid Biology, eds B. E. Funnel and G. J. Phillips (Washington, DC: ASM Press), 509-528.

Thorsted, P. B., Thomas, C. M., Poluektova, E. U., and Prozorov, A. A. (1999). Complete sequence of Bacillus subtilis plasmid p1414 and comparison with seven other plasmid types found in Russian soil isolates of Bacillus subtilis. Plasmid 41, 274-281. doi: 10.1006/plas.1999.1393

Trautwein, K., Will, S. E., Hulsch, R., Maschmann, U., Wiegmann, K., Hensler, M., et al. (2016). Native plasmids restrict growth of Phaeobacter inhibens DSM 17395 energetic costs of plasmids assessed by quantitative physiological analyses. Environ. Microbiol. 18, 4817-4829. doi: 10.1111/1462-2920.13381

Untergasser, A., Cutcutache, I., Koressaar, T., Ye, J., Faircloth, B. C., Remm, M., et al. (2012). Primer3-new capabilities and interfaces. Nucl. Acids Res. 40, e115. doi: 10.1093/nar/gks596

Van Elsas, J. D., Fry, J. C., Hirsch, P., and Molin, S. (2000). "Ecology of plasmid transfer and spread," in The Horizontal Gene Pool; Bacterial Plasmids and Gene Spread, ed C. M. Thomas (UK: Taylor \& Francis), 175-206.

Vanittanakom, N., Loeffler, W., Koch, U., and Jung, G. (1986). Fengycin-a novel antifungal lipopeptide antibiotic produced by Bacillus subtilis F-29-3. J. Antibiot. 39, 888-901. doi: 10.7164/antibiotics.39.888

Walsh, C. T. (2004). Polyketide and nonribosomal peptide antibiotics: modularity and versatility. Science 303, 1805-1810. doi: 10.1126/science.1094318
Wang, X., Kim, Y., Ma, Q., Hong, S. H., Pokusaeva, K., Sturino, J. M., et al. (2010). Cryptic prophages help bacteria cope with adverse environments. Nat. Commun. 1, 147. doi: 10.1038/ncomms1146

Weisburg, W. G., Barns, S. M., Pelletier, D. A., and Lane, D. J. (1991). 16S ribosomal DNA amplification for phylogenetic study. J. Bacteriol. 173, 697-703. doi: $10.1128 /$ jb.173.2.697-703.1991

Wu, H., Qiao, J., Blom, J., Rueckert, C., Reva, O., Gao, X., et al. (2013). The rhizobacterium Bacillus amyloliquefaciens subsp. plantarum NAU-B3 contains a large inversion within the central portion of the genome. Genome Announc. 1:e00941-13. doi: 10.1128/genomeA.00941-13

Yang, Y., Wu, H. J., Lin, L., Zhu, Q. Q., Borriss, R., and Gao, X. W. (2015). A plasmid-born Rap-Phr system regulates surfactin production, sporulation and genetic competence in the heterologous host, Bacillus subtilis OKB105. Appl. Microbiol. Biotechnol. 99, 7241-7252. doi: 10.1007/s00253-0156604-3

Yaryura, P. M., León, M., Correa, O. S., Kerber, N. L., Pucheu, N. L., and García, A. F. (2008). Assessment of the role of chemotaxis and biofilm formation as requirements for colonization of roots and seeds of soybean plants by Bacillus amyloliquefaciens BNM339. Curr. Microbiol. 56, 625-632. doi: 10.1007/s00284-0089137-5

Conflict of Interest Statement: The authors declare that the research was conducted in the absence of any commercial or financial relationships that could be construed as a potential conflict of interest.

Copyright $\odot 2017$ Molinatto, Franzil, Steels, Puopolo, Pertot and Ongena. This is an open-access article distributed under the terms of the Creative Commons Attribution License (CC BY). The use, distribution or reproduction in other forums is permitted, provided the original author(s) or licensor are credited and that the original publication in this journal is cited, in accordance with accepted academic practice. No use, distribution or reproduction is permitted which does not comply with these terms. 